Pace University

DigitalCommons@Pace

$1-1-2000$

\title{
What Do You Do When You Meet a "Walking Violation of the Sixth Amendment" If You're Trying to Put That Lawyer's Client in Jail?
}

Vanessa Merton

Elisabeth Haub School of Law at Pace University

Follow this and additional works at: https://digitalcommons.pace.edu/lawfaculty

Part of the Constitutional Law Commons, Criminal Law Commons, and the Legal Ethics and Professional Responsibility Commons

\section{Recommended Citation}

Vanessa Merton, What Do You Do When You Meet A "Walking Violation of the Sixth Amendment" If You're Trying to Put That Lawyer's Client in Jail?, 69 Fordham L. Rev. 997 (2000),

http://digitalcommons.pace.edu/lawfaculty/160/.

This Article is brought to you for free and open access by the School of Law at DigitalCommons@Pace. It has been accepted for inclusion in Pace Law Faculty Publications by an authorized administrator of DigitalCommons@Pace. For more information, please contact dheller2@law.pace.edu. 


\title{
WHAT DO YOU DO WHEN YOU MEET A "WALKING VIOLATION OF THE SIXTH AMENDMENT" IF YOU'RE TRYING TO PUT THAT LAWYER'S CLIENT IN JAIL?
}

\author{
Vanessa Merton*
}

[A] prosecutor ... enters a courtroom to speak for the People and not just some of the People. The prosecutor speaks not solely for the victim, or the police, or those who support them, but for all the People. That body of "The People" includes the defendant and his family and those who care about him.'

* Associate Dean for Clinical Education and Professor of Law, Pace University School of Law. I wish to thank the District Attorney of New York County, Mr. Robert Morgenthau, and dozens of other assistant district attorneys in his office, for the extraordinary moral, intellectual, and logistical support they provide to help the Pace clinical program create, in the words of another contributor to a Fordham Law Review Ethics Symposium, "[l]aw school graduates with high moral values, an understanding of ethical issues, and a concern for professionalism" and with "a heightened awareness of the [ethical] issues faced in the world of prosecution." Ellen S. Podgor, The Ethics and Professionalism of Prosecutors in Discretionary Decisions, 68 Fordham L. Rev. 1511, 1533 (2000) (calling for law schools to do a better job of educating future prosecutors about the role of the prosecutor and the proper exercise of prosecutorial discretion).

Extra-special thanks to Iris Mercado, Assistant Clinic Administrator, for her heroic effort and outstanding technical ingenuity. Thanks also to colleagues (and former prosecutors and defense lawyers) Adele Bernhard, Stacy Caplow, Ben Gershman, Lissa Griffin, Stephanie Hubelbank, Richard Klein, Holly Maguigan, Martha Rayner, Abbe Smith, Ellen Yaroshefsky, and Steve Zeidman for their helpful comments, too many of which were beyond my capacity to incorporate.

This article is dedicated to Professor Harry Subin, New York University School of Law, 1970-2000, founder of the NYU Criminal Defense Clinic and the NYU Prosecution Clinic, and author of the Subin Report, U.S. Dep't of Justice, Criminal Justice in a Metropolitan Court (1966), who allowed me to collaborate with him on the first Professional Responsibility course I ever taught, and who made me want to be, first, a criminal lawyer; second, a teacher of lawyers; and third, a lifelong student of the complexities of ethical professional life. May I have a fraction of the positive impact on my students that he has had on his.

1. State ex rel. Romley v. Super. Ct., 891 P.2d 246, 250 (Ariz. Ct. App. 1994) (quoting Carol A. Corrigan, On Prosecutorial Ethics, 13 Hastings Const. L.Q. 537, 538-39 (1986) (emphasis omitted)). 
INTRODUCTION: THE PROBLEMATIC RELATIONSHIP BETWEEN ABSTRACT COMMITMENT TO A PRINCIPLE AND CONCRETE BEHAVIOR IN A REAL CASE; OR, HARD CASES MAKE BAD LAWYERS

When I became the faculty supervisor of the Pace Prosecution of Domestic Violence Clinic three years ago, I knew it would not be easy for a long-time defense lawyer to turn prosecutor-even a prosecutor of domestic violence. ${ }^{2}$ And I was not just a defense lawyer, but a hard-core LegAid, ${ }^{3}$ someone who had fallen in love with the New York City Criminal Court as a young student in the New York University Criminal Defense Clinic, and was thrilled when the legendary Marty Erdmann ${ }^{4}$ offered me the job of trial attorney in the

2. I say "even ... domestic violence" because to me the prosecution of these cases leels very different from, say, the prosecution of certain controlled substance offenses under our present drug laws. Prosecutors of domestic violence cannot define success simply as amassing convictions or obtaining severe sentences. The priority for the domestic violence prosecutor ought to be stopping the violence, and whatever creative disposition can be fashioned to do that should be the tactical objective. See American Prosecutors Research Institute, Violence Against Women: The Prosecution of Domestic Violence and Stalking Cases 145, 223-26 (1998); Office for Victims of Crime, U.S. Dep't of Justice, New Directions From the Field: Victims' Rights and Services for the 21st Century 82-90 (1998).

3. "LegAid" is an approximate rendition of the less-than-affectionate term with which criminal defense attorneys on the staff of the Legal Aid Society of New York City were, and are, greeted by some of their clients in the holding pens behind courtrooms-where most client contact occurs-as in "Hey, LegAid! When you gonna get me outta here??" See Jonathan D. Casper, Did You Have a Lawyer When You Went to Court? No, I Had a Public Defender, 1 Yale Rev. L. \& Soc. Action 4, 5-8 (1971); see also Suzanne E. Mounts, Public Defender Programs, Professional Responsibility, and Competent Representation, 1982 Wis. L. Rev. 473, 474 (discussing client suspicion of and hostility toward appointed counsel expressed in "certain refrains which every defender has encountered," such as "I don't want a public defender, I want a real lawyer" or "Did you have an attorney on your last case? No, I had a public defender.")

The Legal Aid Society of the City of New York is the world's largest public interest law firm, public defender, or civil legal services organization. See Legal Aid Society, The Legal Aid Society: The Law Firm for Poor People, at http://www.legalaid.org/lasfaq. By contract, its lawyers are assigned to represent the vast majority of New York City's indigent defendants. See Michael McConville \& Chester L. Mirsky, Criminal Defense in New York City, 15 N.Y.U. Rev. L. \& Soc. Change 582, 641-48 (1986-87).

4. Martin Erdmann was the Attorney-in-Chief of the Criminal Defense Division of the Legal Aid Society of the City of New York and a redoubtable character. During my first year of law school, he achieved national notoriety with the publication of an article called "I Have Nothing to Do With Justice" in the March 12, 1971 edition of Life magazine. In that article, Erdmann was quoted as saying (in his usual temperate fashion), "There are so few trial judges who just judge, who rule on questions of law, and leave guilt or innocence to the jury. And Appellate Division judges aren't any better. They're the whores who became madams. I would like to [be a judge] just to see if I could be the kind of judge I think a judge should be. But the only way you can get it is to be in politics or buy it-and I don't even know the going price." In re Justices of the App. Div. v. Erdmann, 33 N.Y.2d 559, 560 (1973) (Burke, J., dissenting) (quoting Life, Mar. 12, 1971). As a result, Erdmann was 
Criminal Defense Division of the Legal Aid Society of the City of New York.

Soon I was a union delegate for the Association of Legal Aid Attorneys, helping to organize a lengthy and painful lawyers' strike to achieve continuity of representation: i.e., the right to have a relationship with our clients that bore some semblance to the relationship people with money to hire private counsel have with their attorneys. $^{5}$ I became a member of the National Lawyers Guild in 1972, and still am. For five years after I ambivalently left Legal Aid to start teaching in my true alma mater, the NYU Criminal Defense Clinic, I insisted on staying on "temporary leave" and held on to my Legal Aid Society identification card like a talisman to assure me that I was still engaged in righteous work. (I'm sure I have it somewhere to this day.) Some of my closest friends, and many of my favorite students, are long-time LegAids. And I never "burned out," although I certainly had some burnt-out moments, of the sort so poignantly captured in Randy Bellows' Notes of a Public Defender. ${ }^{\circ}$

More than that, I had always seen the prosecutor's job as comparatively, well, straightforward ${ }^{7}$-nowhere near the challenge of trying to help, on myriad levels, an indigent defendant who was almost always in jail, with few real friends, a dysfunctional family, scant education or coping skills, and frequently tormented by drug withdrawal. The prosecutors, it seemed to me, could sit and wait until the cops brought them cases, if not on a silver platter, at least in a file: witnesses, evidence, and a coherent enough story to have occasioned an arrest. If a prosecutor needs more help to put the case together, all she has to do is call on the cops or on the array of other resources at

brought up on disciplinary charges and found guilty of professional misconduct by the Appellate Division, Third Department, which censured him. Id. at 559. A few weeks before I took the bar exam and started work at Legal Aid, he was exonerated on appeal. Id. at 560. Ultimately, inevitably, he was himself elevated to the Criminal Court bench.

5. The travesty of discontinuous representation characteristic of the Legal Aid Society and other institutional defenders during this period is well described in the horrendous but entirely routine experience of the defendant in Unired States ex rel. Thomas v. Zelker, 332 F. Supp. 595, 601 (S.D.N.Y. 1971) (reversing conviction because of ineffective assistance by the Legal Aid Society.) In this case, over a fivemonth period, Legal Aid provided from five to nine different attorneys, many of whose names could not be determined, and none of whom had ever met with the defendant's prospective witnesses or conducted any other factual investigation prior to his trial. See id. at 597-98; see also Wallace v. Kern, 392 F. Supp. 834, 836-40 (E.D.N.Y. 1973), rev'd on other grounds, 481 F.2d 621 (2d Cir. 1973) (describing Legal Aid Society clients who suffered from fragmented representation, caseloads that were incompatible with competent representation, and frequent guilty pleas with no prior investigation of defenses).

6. Randy Bellows, Notes of a Public Defender, in Phillip B. Heymann \& Lance Liebman, The Social Responsibilities of Lawyers: Case Studies 69 (1988).

7. See Abbe Smith, Defending the Innocent, 32 Conn. L. Rev. 485, 509-13 (2000) (contending that a defense lawyer must become more of a "creative artist" than a prosecutor). 
her disposal. If subpoenas need to be served, if a site should be photographed, if a witness needs a ride home, if the ADA wants to talk to five other guys who hang out on the same block as the perpetrator, if she wants a rap sheet on a character witness-all could be arranged. ${ }^{8}$ Meanwhile, I could try going up to a bar at 138th and Lenox at 2:00 a.m. to see if I could find a red-haired guy called Diablo who didn't want to be found, because according to my client, "Diablo saw the whole thing-some other dude did it."9

The point is not that I have some good war stories to tell, but that it is important to acknowledge the impact of early, formative experiences of professional socialization on the ethical and moral perspective that a lawyer brings to bear on his experience. It is no accident that former prosecutors and former defense lawyers appointed to the criminal court bench render diametrically opposed decisions on similar facts, applying the same law. Nor (with a couple of notable exceptions) is it the product of conscious bias, if by that is meant an intentional effort to assist former colleagues or adhere to an ideological commitment. But every lawyer who practices at 100 Centre Street ${ }^{10}$ (all right, every good lawyer) is well aware of the professional pedigree of the judges before whom we appear, and we adjust our expectations and tactics accordingly. ${ }^{11}$ As a lawyer who

8. Lest any D.A.N.Y. colleagues who might read this start to sputter, I want to say emphatically that three years as a quasi-prosecutor have disabused me of this notion - or rather, balanced it with an experiential sense of just how difficult it is to build, and then maintain through the insanity of the urban criminal justice process, a case that is free from reasonable doubt.

However, many other ex-prosecutors now in a position to reflect on their experience do not hesitate to acknowledge the advantages inherent to the prosecution. See, e.g., Bruce A. Green, Why Should Prosecutors "Seek Justice"?, 26 Fordham Urb. L.J. 607, 625-29 (1999) [hereinafter Green, Why Should Prosecutors "Seek Justice"?].

9. A frequent enough formulation to earn the sobriquet among LegAids of the "SODDI defense" - to be distinguished from the "Chicago defense" as in "I've been thinking about moving to Chicago ..."

10. 100 Centre Street refers to the address of the Criminal Court of the City of New York, New York County, and the Supreme Court of the State of New York, Criminal Term, New York County.

11. Of course, there are identifiable reverse-prototypes: for example, Harold Rothwax, the brilliant, bitter "Prince of Darkness," as both sides came to call him during the more than a quarter-century that he presided over criminal cases in New York County. Justice Rothwax, who had spent six years as a Legal Aid Society trial attorney, and founded and directed the early community-based legal services office, Mobilization for Youth, became progressively more disenchanted with the rights of the accused. His controversial book, Guilty: The Collapse of Criminal Justice, severely criticizes such basic decisions as Miranda v. Arizona, 348 U.S. 436 (1966), and is the most chillingly anti-defendant accourt of the criminal justice system I've ever read. Harold J. Rothwax, Guilty: The Collapse of Criminal Justice 85-87 (1996); see also Richard Klein, The Relationship of the Court and Defense Counsel: The Impact on Competent Representation and Proposals for Reform, 29 B.C. L. Rev. 531, 553-54 (1988) [hereinafter Klein, The Relationship of the Court and Defense Counsel] (describing Justice Rothwax's handling of cases). I'm not aware of any 
once could no more have dreamed of becoming a prosecutor than of changing my gender, who is still greeted with disbelief by former comrades when they see me stand behind a student on the prosecutor's side of the table, ${ }^{12}$ but who now seeks, through my student assistant district attorneys, to protect victims and stop their criminal abuse as relentlessly as ever I fought for a client's freedom, ${ }^{13}$ I bring a tangle of perceptions and values acquired over more than two decades to this analysis. It would be naive to think that doesn't matter.

For the purpose of this article, the relevance of my experience is this: if ever one might expect to find a prosecutor inclined to err on the side of fairness of process and protecting the rights of defendants, it ought to be me. Also, for more than twenty years, I have been something of a professional ethicist - as research fellow, teacher, staff member of an ethics center, chair and/or member of several institutional review boards, pro bono trial counsel to a disciplinary

counterexamples of former prosecutors adopting a predictably pro-defendant stance, although no doubt they exist. But whichever way the experience skews a judge's perspective-for or against his former position-almost always it has a palpable, and in many cases powerful, effect.

12. To old defense friends who look askance at my metamorphosis, I can say only that in working with students who seem bound to become career prosecutors, I consciously try to inculcate, almost inoculate, them with a clear sense of the prosecutor's uniquely nonadversarial role. I believe in it, I explicitly teach about it, and I model it. This multifaceted role includes elements of neutral objectivity and dispassionate evaluation not only of the facts of a case, but of their legal, social, and moral implications. See H. Richard Uviller, The Neutral Prosecutor: The Obligation of Dispassion in a Passionate Pursuit, 68 Fordham L. Rev. 1695, 1697-1705 (2000). While all lawyers may have to temper their dedication to the client's interest with some degree of fidelity to the court and the legal process (for an excellent analysis of this point see Kevin C. McMunigal, Are Prosecutorial Ethics Standards Different?, 68 Fordham L. Rev. 1453, 1458-61 (2000)), this dual function is more dominant and demanding for prosecutors than for most attorneys who represent clients. "Although the prosecutor operates within the adversary system, it is fundamental that the prosecutor's obligation is to protect the innocent as well as to convict the guilty, to guard the rights of the accused as well as to enforce the rights of the public." ABA Standards for Criminal Justice: Prosecution Function and Defense Function 5 (3d ed. 1993).

13. Strange as it might seem to a British barrister, see Bennett L. Gershman, The New Prosecutors, 53 U. Pitt. L. Rev. 393, 456 (1992), or to the many alums of the New York County DA's office who have become highly successful private defense counsel, I decided when I joined this program that there would be no going back. I do not expect ever to practice criminal defense again, unless perhaps in an isolated case involving someone like a member of my family (God forbid!), and even then, never in New York County. While technically there would be no breach of ethics, see N.Y. Code of Prof'l Responsibility DR 9-101(b)(3) (1999) [hereinafter N.Y. Code], so long as it was not a case that the Pace Prosecution of Domestic Violence Clinic had handled, for me it would be a breach of trust. I know that my understanding of the way a defense lawyer thinks and strategizes is advantageous for my students, and I'm sure that all I've absorbed by osmosis from the DA's office would benefit me were I to return to the defense side. It would not seem right to so exploit the access and acceptance I've experienced in this office. 
committee, ethics consultant, and expert witness - and, therefore, one might think, especially susceptible to the weight of ethical discourse and analysis.

What prompts me to write about the case and the issue that are the subject of this piece is that despite all the above, when the critical moment came in this particular case - with a particular complainant who was terrified and desperate, and a particular defendant who (to me) was not only guilty but dangerous - I could not bring myself or require my students to intervene to assure the defendant his constitutional right to competent representation, even though in the abstract, I believe that to be a prosecutor's duty. I hasten to add that not all prosecutors would agree, and that this duty is nowhere specifically imposed on prosecutors in the applicable codes of ethics. ${ }^{14}$ I doubt that I could be disciplined for what I did, or rather, failed to do. However, as someone committed in principle to the concept of "ethical discretion in lawyering"15 that is so much in vogue in the literature these days, and cognizant of its special merit in the prosecutorial context, I generally treat the ethics code as a floor, not a ceiling, for my conduct. Unanimity or broad approbation has never been my touchstone for ethical decision-making; in fact, a significant component of my curriculum revolves around acquiring the capacity to choose knowledgeably among competing role-definitions, and to depart, when correct to do so, from the standard professional norm. ${ }^{16}$

14. Inability to find "authority" for an ethical proposition-i.e. its codification in a principle or rule, an ethics committee opinion, or judicial exegesis-has never been of great moment in my ethical decision-making because I tend to view these as precatory, even though they may be framed as mandatory.

Ethical precepts for lawyers do not evoke compliance because sanctions are theoretical, given the reality in most jurisdictions that violations are detected and disciplined at a rate that makes enforcement of the apocryphal prohibition on mattress-tag removal look successful. Most of the time, most lawyers will get away with violating ethics codes, if they choose to do so; the utility of the codes et al. for the lawyer confronting a prospective dilemma (rather than judging past behavior) seems to me as an historical account of the thinking of many wise, respected, and caring lawyers, and a distillation of the recommendation one might expect if able to consult them directly.

When analyzing my own ethical responsibilities as a prosecutor, and as a supervisor and teacher of prosecutors, I insist that we review all available resources and authorities, whether or not they happen to be binding in our jurisdiction, or even if they have been overturned by a subsequent decision, because, for our purposes, all is grist for our mill. This is not to suggest that I make no effort to assess the likelihood that a particular choice could bring opprobrium on our parent office, humiliation on our law school, or difficulty to the bar admission of the students; the codification of a specific duty may be a significant factor in that calculus. Such a prediction does not, in and of itself, tell us whether a proposed course of action is "right."

15. See, e.g., William H. Simon, Ethical Discretion in Lawyering, $101 \mathrm{Harv}$. L. Rev. $1083,1090-91$ (1988) (stating that a lawyer should always take actions that, in a particular case, are most likely to promote justice; this model of lawyering is inspired by the example of prosecutorial discretion).

16. One of the primary evaluation criteria of our clinical program is:

Developing sense of responsibility for professional choices and their consequences 
So the lack of specific direction from the law of lawyering does not explain my failure to take the ethical measures that, in the abstract, I espouse.

While few academics or bar counsel seem even to have considered the question of the prosecutor's responsibility for the quality of a defendant's representation, ${ }^{17}$ as I will discuss, more than one scholar has persuasively asserted that this duty exists. ${ }^{18}$ I find their analyses

Recognition of ethical issues and relevant professional norms and standards; Ability to research professional ethics; Ability to analyze critically the validity of professional norms and standards; Ability to recognize and choose among conflicting professional norms and personal values; Ability and inclination to articulate reasoning behind ethical choices; Coherence and consistency of ethical reasoning.

17. I make such a statement with more trepidation than temerity, awaiting the inevitable appearance of a recent and comprehensive law review article on this precise point located by one of my readers, or preferably, one of the editors of this Symposium. Among the sources consulted in search of guidance were the following:

(1) The Annotated Model Rules of Professional Conduct (4th ed. 1999): the Rule, Comment, and Legal Background of the following sections: Preamble (A Lawyer's Responsibilities), Rules 1.1 (Competence), 1.3 (Diligence), 1.4 (Communication), 3.4 (Fairness to Opposing Party and Counsel), 3.5 (Impartiality and Decorum of the Tribunal), 3.8 (Special Responsibilities of a Prosecutor), 4.2 (Communication with Person Represented by Counsel), 4.3 (Dealing with Unrepresented Person), 8.3 (Reporting Professional Misconduct), and 8.4 (Misconduct);

(2) The ABA/BNA Lawyer's Manual on Professional Conduct (1999): $\S \S 31: 201-31: 509$ (Competence, Diligence, and Communication), 61:60161:630 (Prosecutors), and 101:201-101:208 (Reporting Misconduct);

(3) Charles W. Wolfram, Modern Legal Ethics (1986): Chapter 5 (Lawyer Competence); $\$ \S 12.10$ (Disclosing Lawyers' Misconduct), 13.10 (Prosecutors), and 14.6 (Effective Assistance of Counsel);

(4) The ABA Standards for Criminal Justice: Prosecution Function and Defense Function (3d ed. 1993);

(5) National District Attorneys' Association, National Prosecution Standards (2d ed. 1991), \$\& 6.1-6.5 (Professionalism), 24.1-24.6 (Relations With the Defendant), 25.1-25.6 (Relations With Defense Counsel);

(6) John Jay Douglass, Ethical Issues in Prosecution (1988);

(7) Randolph N. Jonakait, The Ethical Prosecutor's Misconduct, 23 Crim. L. Bull. 550 (1987);

(8) Bennett L. Gershman, Prosecutorial Misconduct (2d ed. 1999); Bennett L. Gershman, The New Prosecutors, 53 U. Pitt. L. Rev. 393 (1992); Bennett L. Gershman, Why Prosecutors Misbehave, 22 Crim. L. Bull. 131 (1986); and

(9) all of the articles in last year's Symposium: Ethics in Criminal Advocacy, 68 Fordham L. Rev. 1371-1718 (2000).

18. See principally Fred C. Zacharias, Structuring the Ethics of Prosecutorial Trial Practice: Can Prosecutors Do Justice?, 44 Vand. L. Rev. 45, 66-74 (1991) [hereinafter Zacharias, Structuring the Ethics] (suggesting possible interventions by a prosecutor when defense counsel's performance is "substandard"); see also Bruce A. Green, Her Brother's Keeper: The Prosecutor's Responsibility' When Defense Counsel Has a Potential Conflict of Interest, 16 Am. J. Crim. L. 323, 324 (1989) [hereinafter Green, Her Brother's Keeper] (noting that a prosecutor has a duty to "ensure that a criminal defendant is not unjustly convicted and that the proceedings leading up to a conviction are fair"). For a further discussion of Structuring the Ethics, see infra notes 62-88 and accompanying text. For a further discussion of Her Brother's Keeper, see 
logical, the predicted impact on the criminal justice system positive in utilitarian terms, and the concern for defendants' rights appealing. In the case described below, I had the perfect opportunity to act in accord with both my intellectual beliefs and my political instincts. Why, then, did I fail to do my duty? While in twenty-seven years of practice my students and I have certainly made ethical errors and arrived at misjudgments, I cannot recall another occasion when, having reached closure on an ethical decision, I simply failed to implement it.

Or did I? Perhaps it's not that I lacked the ethical will to adhere to the course of action that in theory I embraced. Perhaps I was, albeit somewhat unconsciously, engaged in the perfectly respectable practice of casuistry: a "particularized, context-driven method" of ethical decision-making. ${ }^{19}$ One question I address later in this article is the legitimacy of a prosecutor's use of casuistry under any circumstances. The more troubling question, however, is whether, in this instance and in others, casuistry can become "just another word"20 for the gap between commitment to an ethical principle and performance in accord with that principle in a particular case.

This experience has taught me that, ironically, taking the textured, nuanced, and casuistric approach to ethical decision-making grounded in the prosecutor's noble-sounding "duty to do justice" can offer a convenient-nonetheless valid, perhaps, but convenient-rationale for prosecutors not to protect a defendant's right to competent counsel. Absent an explicit, codified directive, it is easy-I will not (yet) say too easy, but definitely easy - to decide that the prosecutor's generic duty to do justice does not require a prosecutor to try to rectify the perceived inadequacy of defense counsel in a particular case. Even when defense counsel's deficiency is so blatant that it would seem to present a "paradigm case", in the parlance of casuistry, ${ }^{21}$ the overall context of the realities of both the urban criminal justice system and the lawyer disciplinary system may seem to justify a different choice. Taking the case-by-case approach even to a much more specific rule, like the rule requiring lawyers to report other lawyers' misconduct, likewise may not generate sufficient impetus to compensate for the countervailing factors.

One way to frame the question is: When a prosecutor encounters a defense lawyer who seems to be neglecting a client or grossly mishandling the defense, to a degree that constitutes a violation of the

infra notes 51-61 and accompanying text.

19. Paul R. Tremblay, The New Casuistry, 12 Geo. J. Legal Ethics 489, 492 (1999) [hereinafter Tremblay, The New Casuistry].

20. "Freedom's just another word for nothing left to lose ..." Kris Kristofferson, Me and Bobby McGee (Monument Records 1971).

21. Tremblay, The New Casuistry, supra note 19, at 517-19. 
applicable ethical code, what, if anything, does the prosecutor have an ethical obligation to do?

Posed in the abstract, an ethics junkie like myself should have had no trouble answering: "Plenty." And yet, embodied in an actual case, the answer became far murkier.

The problem is illustrated by the following story-which, considering what I believe to be the unsettled state of professional ethics on this point, let us say is entirely hypothetical. So: imagine that this, or something like this, happened this spring. For if it did not, surely no one familiar with 100 Centre Street can doubt that it could have. Yet, prior to (imagining) having witnessed this scene, in more than twenty-five years of practice and deep and energetic study of professional ethics in general and prosecutorial ethics in particular, this question had not occurred to me.

\section{WHO WAS THAT MASKED MAN?}

\section{A. The Student ADAs ("SADAs") Meet Opposing Counsel}

It was a typical scene outside an All-Purpose Part of the Criminal Court, ${ }^{22}$ which I won't even try to describe except with a few words and phrases that do not do it justice: hot, smelly, dirty, noisy, crowded, crying children, drunk or drugged derelicts, bored cops, frantic lawyers racing to distant courtrooms, court officers trying to locate absent lawyers, pay phones ringing, cell phones ringing, a kind of lackadaisical pandemonium. ${ }^{23}$ (Can't you see why I love the place?)

Two of my SADAs had been told that the defense lawyer on one of their cases had "signed in" with the court officers, which meant he might, or might not, be in the environs. They had been trying for weeks to contact this lawyer; he had not appeared at two prior court dates, nor responded to nearly a dozen phone and fax messages. We had concerns about the victim's somewhat fragmentary description of this crime. The SADAs wanted to hear from the defense attorney, as much as he would tell us, the defendant's side of the story. This was a first arrest, with no apparent prior history of abuse, no serious injury, ${ }^{24}$ and the SADAs wanted to know if there were weaknesses or inconsistencies in the victim's story that should give us pause. (One of the strong ethical precepts reinforced in the Prosecution of Domestic

22. For an equally dire picture, but constructed with facts and figures rather than adjectives, see Harry I. Subin, The New York City Criminal Court: The Case for Abolition, Center for Research in Crime and Justice, New York University School of Law, Occasional Papers No. XII (Graham Hughes ed., 1992).

23. For a fuller description of the "physical squalor" of lower criminal courts in most American cities, see Abbe Smith, Carrying on in Criminal Court: When Criminal Defense is Not So Sexy and Other Grievances, 1 Clinical L. Rev. 723, 741-45 (1995).

24. N.Y. Penal Law $\S 10.00(9)$ (McKinney 1998). 
Violence Clinic is that we don't plea-bargain, or even $A C D,{ }^{25}$ cases that we believe lack merit. We dismiss them. I should add that we've dismissed precious few cases; our holistic, victim-centered approach ${ }^{26}$ to family violence prosecution has enabled us to find substantial evidence of guilt in the great majority of our cases.)

As the SADAs sought their quarry, I was hovering within earshot, yellow pad poised for note-taking on their communication skills, negotiation, fact investigation, professionalism, and, of course, their ethical awareness. And, as is always the case, I was operating on our standard protocol that I do not speak or intervene or second-guess or participate unless (1) the SADA invites me to, or (2) I see irrevocable and serious error about to be committed. ${ }^{27}$

25. "ACD" is the acronym used in New York state courts to refer to a disposition of "adjournment in contemplation of dismissal." See N.Y. Crim. Proc. Law § 170.55(2) (McKinney 1993 \& Supp. 2000) (allowing adjournment sine die on consent of both the People and the defendant, which will lead to an eventual dismissal "in furtherance of justice" unless, within six months (or a year if a family offense), the People request and the court grants restoration of the case to the calendar (typically because of a rearrest)).

26. See Stacy Caplow, What if There is No Client?: Prosecutors as "Counselors" of Crime Victims, 5 Clinical L. Rev. 1, 35-43 (1998) (proposing a "victim-centric" model of increased communication with and participation by victims, especially in decisions on charging, plea bargaining, and sentencing). Professor Caplow, Director of Clinical Education at Brooklyn Law School, is another former LegAid who has switched sides; she was the Director of Training in the Kings County DA's office, and this year, she is a visiting faculty member in the NYU Law School Prosecution Clinic.

27. Another topic that has inspired a large literature, and that poses perhaps THE single toughest pedagogical question for clinical faculty, is what we denominate as "intervention." Ideally, clinical teachers would be human recorders, watching our students pro-actively take the initiative in every minute detail of planning and execution of lawyering tasks, albeit preceded and followed by didactic instruction, simulated preparation, out-of-role consultation, case conferences, late-night phone calls, review of documents, critique of performances, e-mailed exchanges, and so forth-but no outright intervention, no stepping in to take over the job. As I ceaselessly tell and write and remind and exhort my students, my co-supervisors, and myself, it is harder to learn from undoing or redoing OTHER people's mistakes, or from watching someone else do it "RIGHT," than from experiencing the consequences of one's own choices, including the inevitable mistakes. This is sort of the "Prime Directive" of what I, diehard old dinosaur that I have become, consider true clinical teaching.

Among clinicians, the ethical and moral issues of allegedly using clinic clients as "guinea pigs" for hapless students to learn their craft have been exhaustively debated, the countervailing rationales well-presented, and the analogues to the health professions identified. Readers may refer to a rich literature. See, e.g., David F. Chavkin, Am I My Client's Lawyer?: Role Definition and the Clinical Supervisor, 51 SMU L. Rev. 1507 (1998); George Critchlow, Professional Responsibility, Student Practice, and the Clinical Teacher's Duty to Interverie, 26 Gonz. L. Rev. 415 (1991); Peter Toll Hoffman, The Stages of the Clinical Supervisory Relationship, 4 Antioch L.J. 301 (1986); Kenneth R. Kreiling, Clinical Education and Lawyer Competency: The Process of Learning to Learn From Experience Through Properly Structured Clinical Supervision, 40 Md. L. Rev. 284 (1981); Michael Meltsner et al., The Bike Tour Leader's Dilemma: Talking About Supervision, 13 Vt. L. Rev. 399 (1989); Ann Shalleck, Clinical Contexts: Theory and Practice in Law and Supervision, 21 N.Y.U. Rev. L. \& Soc. Change 109 (1993-94); James H. Stark et al., Directiveness in Clinical 
I could see that the SADAs were a bit taken aback by the demeanor of the man who finally responded to their calls of "Mr. Defender! Is the lawyer for Juan Cliente ${ }^{28}$ here?" All along, he had been leaning against a wall, scribbling with a pencil on a stack of files. $\mathrm{He}$ had no briefcase or satchel or backpack to hold a handy CPL or Penal Law. He was, to put it politely, unkempt: flushed, perspiring, uncombed, unshaven, shirt-tails hanging out of his trousers. ${ }^{29}$ My first

Supervision, 3 B.U. Pub. Int. L.J. 35 (1993); see also Association of American Law Schools Section on Clinical Legal Education, Final Report of the Committee on the Future of the In-House Clinic (August 1990) (discussing guidelines and educational structure of in-house clinics).

For me, with age and experiential learning (life imitating art imitating life?) has come less frantic a need to make sure the student gets it right the first time, because experience has so often shown that what I was positive was "right" for the lawyer in the situation in a given moment, actually wasn't, and about equally often, the horrendous student error that I was gripping my chair in an effort not to rise to address has turned out to be a brilliant strategic stroke. In the particular context of Criminal Court, I find reassuring my colleague Steve Zeidman's empirical investigation of the relative quality of representation provided by defense clinic students and that of institutional defenders. See Steven Zeidman, Sacrificial Lambs or the Chosen Few? The Impact of Student Defenders on the Rights of the Accused, 62 Brooklyn L. Rev. 853 (1996) (concluding that students provide superior representation both in terms of results achieved and in their performance of lawyering tasks).

28. I preserve the Hispanic appearance of the client's name only because of a later, repeated slip of the tongue (or worse) by Mr. Defender that contributed to our overall assessment of his representation. It may well be that the obligation to take action in the face of defender incompetence is even greater when that incompetence is coupled with blatant racism, sexism, heterosexism, etc. Increasingly the organized bar is recognizing the incompatibility of bigotry with professionalism. See, e.g., N.Y. Code, supra note 13, DR 1-102(A)(6) (prohibiting unlawful discrimination in the practice of law on the basis of age, race, creed, color, national origin, sex, disability, or marital status); Comment to Model Rule 8.4 as amended by the ABA House of Delegates in 1998 (during client representation, professional misconduct for lawyer to manifest prejudice on the basis of race, sex, religion, national origin, disability, sexual orientation, or socioeconomic status "when prejudicial to the administration of justice") (discussed in Annotated Model Rules of Professional Conduct $584\left(4^{13} \mathrm{ed}\right.$. 1999)). However, I have been unable to locate any judicial decision or ethies opinion equating such prejudice, even when directed at the lawyer's own client, with either ineffective assistance or Canon 6 incompetence.

29. Deliberately, because I think it would distract from my major point, I am not going to identify whether this attorney was: (1) a staff attorney from the Legal Aid Society; (2) a member of one of the alternative contract defenders offices that, in the wake of the last Legal Aid Society lawyer strike, received contracts from the City of New York to handle a certain number of criminal cases, so that the City will never again be wholly dependent on Legal Aid for the bulk of its criminal docket; or (3) a private practitioner who has been permitted to join the "18-B" panel of lawyers who receive rotating assignments to criminal cases at a statutory fee rate that is the rough equivalent of what Medicaid pays psychiatrists-i.e., about $20 \%$ of the going rate per hour. See Gary Muldoon \& Sandra J. Feuerstein, Handling a Criminal Case in New York 2-5 to 2-8 (1999). He could have been any one of these, and quite possibly at various points in his career, all of them. The one other fact about this lawyer that I will reveal is that, long ago. he had been an Assistant District Attorney, although I will not say in which office.

I am quite certain that this attorney's prior or current institutional affiliations had 
thought was he must be unusually dedicated to come to court when he was so obviously sick with the flu.

As it developed, that didn't seem to be the problem.

Aha, you say, he was drunk. Or on drugs. Or needed to get drunk or high. Well, maybe. My once keenly discerning internal substanceabuse-detector didn't register that, though. No, Mr. Defender's difficulties were perhaps even more deep-seated.

One SADA began with the usual, "Hi, Mr. Defender, my name's Jennifer Ling and this is my colleague Dan Jones; we're the student assistant district attorneys assigned to the case of your client, Juan Cliente, and we were hoping to talk with you about - "

Mr. D: What the hell are you, anyway? Asian? Another goddam immigrant I have to deal with? Bad enough I have all these Mexican bastards for clients. Which one is this, now? (Shuffling through files.) Sanchez, you said? Yeah, another one who doesn't even speak English. I'd like to know what we're supposed to do when our clients can't even speak the damn language.

[A longer pause than is usual. I suggest to my students as a general stance of litigation, seizing the momentum, taking command of the situation, if in front of a judge, stepping into the silences (unless the judge is reading something), etc., etc. However, in this instance, I thought my students' silence both understandable and perhaps the best strategy for the moment, since I sure couldn't think of what to say.]

SADA Jones: Uh, Mr. Defender, we've been trying to get hold of you because we thought it might make sense to get an idea...

Mr. D: Okay, here it is-Sanchez, yeah, another car thief. Probably young, though, you know? Maybe not such a bad kid-maybe he does it to support his dear mother. (Head thrown back, a gleeful guffaw over his own wit.) What are you looking for? These guys don't care if they get a conviction as long as there's no jail. How 'bout a fine? He can always steal another car to pay it. (Another raucous guffaw that descended into a giggle. Then he started working on something in his ear.)

[At this point I'm wondering whether, after all these years,

zero impact on our ethical decision-making. Arguably, a prosecutor might have reason to believe that intervention would be more effective, and therefore more obligatory, if the offending lawyer were institutionally-based rather than a Lone Ranger, because a "supervisor" might want to maintain credibility with the DA's office; on the other hand, defense lawyers, who certainly can be viciously critical of one another, have a long tradition of closing ranks and refusing to acknowledge bad behavior when the issue is raised by an outsider, especially an outsider viewed as hostile. Were I a supervisor at Legal Aid or another institutional provider of defense services, I would certainly look askance at a complaint of misfeasance emanating from the DA's office, and would be quick to suspect that it had been prompted by an excess, not a deficiency, of zeal on the part of my staff attorney. 
someone has actually set me up, as some kind of weird joke, with a genuine actor from Central Casting, parodying the type of revolting, rip-off artist, sleazebag defense lawyer that still haunts our criminal justice systems, whether from the assigned counsel panel or the public defender or private criminal defense offices. Was today April 1? My birthday? No. There was no obvious explanation why someone would do such a thing today.]

SADA Ling (recovering): Actually, no, Mr. Defender, the case we're on is Mr. CLIENTE, that's C - L - I - E - N - T - E, not Sanchez. And it's not a car case, it's...

Mr. D: You wanta tell me why there are two of you guys ganging up on me on one lousy piece of sh-t misdemeanor? What'd I do, win the lottery or something?

[So, Mr. Defender and I were having similar reactions of confusion and disbelief....]

SADA Ling: You see, Dan and I are both third-year law students in the clinical program at Pace Law School-

[Good, Jennifer. He's upset that there are two of you. Better to have you continue than to have Dan chime in and double-team him...]

Mr. Defender steps back, flinging his arms up as if he's been shot, with an inarticulate cry of dismay and disgust.

Mr. D: STU-U-DENTS!!! What ya kidding me, students??? Now I gotta deal with this? Naaah, I don't think so. I don't have time for this. Sorry, you look like nice kids, but the defendant has rights, too, you know. This is $f---g$ ridiculous, I've had "STU-U-DENTS" before-the worst time was the one supposed to be my co-counsel, HAH! THAT was a joke!!! (Pause.) Hey, Pedro or whatever your name is, come over here. You got lucky, buddy, you're gonna be prosecuted by STU-U-DENTS this time.

None of us on the prosecution team had noticed in the human kaleidoscope of the hallway that the defendant, Mr. Cliente, had left the courtroom where we'd last seen him and was now standing several feet away from Mr. Defender. Mr. Cliente, as always on his court dates, was neatly dressed and clean-shaven and carrying a small leather portfolio under his arm. He responded to Mr. Defender's overture slowly (certainly understandable) and came only a little closer. It was evident to us that he did not appreciate being addressed as "Pedro" (his name was Juan). Mr. Cliente was actually well aware that Jennifer and Dan were law students certified and authorized to practice as student assistant district attorneys because on at least one of his court dates, that had been explained to the presiding judge, who was unfamiliar with the phenomenon. 
Mr. D: Yeah, folks, okay, so this is your man. This is Pedro. Now, listen Pedro, how much was that car worth anyway - can you pay it back, you know, make restitution-

[Jennifer and Dan look at each other and then simultaneously turn back toward me for a moment-something we all generally try to avoid in mid-event - but the good news was, both my students clearly recognized something large and irrevocable and unusual was happening here, and that this just might be a moment when I would have to intervene. And I am thinking, they got THAT right. WHAT the hell am I going to do? Is this bozo seriously asking his client to confess to a crime in front of us? Okay, but wait a minute, he's talking about the wrong case. We know that Mr. Cliente is guilty-if he's guilty - of a misdemeanor assault and destruction of property, and we're concerned about possible stalking subsequent to the arrest and the protective order, but nothing about a car, so ... When in doubt, when I don't at the moment have any reason to think that my impulse is any more or less strategic or ethical than my students', that is not when I'm going to intervene ... . ]

Mr. C: Look, Mr. Lawyer, you keep trying to talk to me about a car, I keep telling you I don't know what you're talking about, no one said nothing about a car. It's just a little problem I had with my wife, she's sorry about it now, I know it can all be cleared up, she doesn't want me to go to jail. Look, I have to get out of here. I have to get to work-I already missed three days of work. Please, can we just take care of this...

Mr. D: First of all, buddy, don't call me Mr. Lawyer, that's not my name, my name is Bob Defender, I don't know why the hell you can't get that straight...

$$
* * * *
$$

Fearing that continuing the blow-by-blow dialogue will get old, I want to fast-forward past the interchange about who was getting whose name wrong, and Mr. Cliente's increasingly impassioned pleas for Mr. Defender to listen to him, to understand what the case was about, to go back into court and make whatever had to happen, happen, before he lost his job, and Mr. Defender's rude and sarcastic insistence that Pedro better listen to him and so forth, while the three prosecutors stand there quite literally speechless. By now I could see that it had dawned on Dan and Jennifer that, specifically, what they were doing was eavesdropping, more or less by invitation of the lawyer, on a lawyer-client consultation; that a large red neon sign inside their brains was flashing; and that they were trying to figure out what they should be doing, knowing all too well that what they wanted to be doing was unceremoniously walking away, or better yet, for me to be telling them what they should be doing. 
It was probably only three or four minutes, though it did seem longer, before Dan came up with an approach: "Uh, Mr. Defender, Mr. Cliente, maybe you'd prefer that we try to talk later about this-"

Mr. D: Whadyya TALKIN' about, kid? I don't have all day. Maybe you only have one lousy case, but I got a lot more important cases than this, believe me... So, what's it all about? It's a family dispute? Take it from me, you don't have the experience yet-it's no big deal. I'm sure they're back together. (To Mr. Cliente:) Everything going okay with the wife now, buddy? You're living together again, right? She just got a little carried away, but you're not gonna hold it against her, right?

Mr. C: Right now we CAN'T live together. Don't you know? You never answer the phone, you never return my calls, I keep trying to talk to you about this. My wife of course she wants me home, but this case has to be over. It's costing a lot of money for me to stay someplace else. You don't care, you don't do nothing-

Mr. D: Whoa, buddy, listen to me, you're damn lucky I'm talking to you now, take it easy-look, just tell us what the situation is and I'm telling you, it's gonna get straightened out. We can probably get rid of this meatball today, right, guys? (Now turning back toward SADAs Ling and Jones, and smiling as if they were good buddies.) After all, you may be students, but you look like reasonable people. You're not gonna make a federal case out of something like this. It's a waste of your time, too, 'cause it's not going anywhere. You wanta get yourselves some experience with some REAL cases, some drug cases or something where you can do some hearings, maybe go to trial even. Not this piece of garbage... (Turning back to Mr. Cliente.) Listen, buddy, you have any kind of record? You ever been arrested for this kind of thing before? Ever go inside before?

Mr. C: No, no, I'm not that kind of man, it was a misunderstanding-

Mr. D: (Turning back to SADAs Ling and Jones.) Yeah, okay, see, this is a stand-up guy, it was just one of those things, a little argument gets out-of-hand and everybody gets upset and now these cops, you know how hungry they are for arrests, we're getting a million of these family disputes now, all bullsh-t, trust me... Look, Pedro-

Mr. C: NOT PEDRO!! My name is JUAN!!

Mr. D: Okay, jeez, look, just tell these nice people what happened with you and your wife so we can get outta here, will you? Come on, so you were just going home after a hard day's work ...

Mr. C: (Somewhat hesitantly.) Yes, well, no, she was actually the one who came home, late you know, much later than she should 
have... She thinks I don't know that she has a boyfriend. She thinks I'm jealous for no reason. It's not that ...

[As Mr. C continued to recount, soon with gestures, the sequence of his beating and threatening his wife and destroying precious possessions of hers in the apartment-how, after his release from custody and signing the protective order promising to leave his wife completely alone, he had promptly proceeded to the home of her friend, where she was staying, and chastised her for calling the police and making him endure several hours of custody; and how she had been ashamed and repentant and promised never to do anything so foolish again - I was listening, but with only half a brain. The other half kept thinking: Is this really happening? There's no punch-line here; this is NOT exculpatory. What does this lawyer think he's doing? IS he a lawyer? It actually crossed my mind that some radical activists had somehow arranged to have this ringer assigned to domestic violence cases, and that everyone else-supervisors, judges, probation officers, etc.-who must have seen this lawyer (actor? lawyer-impersonator?) in action had decided not to intervene because in so many of these cases the defendants richly deserve punishment. If this is what I'm thinking, what must my students be thinking? I look at them; they appear spell-bound, almost entranced.] Then, with a visible effort, SADA Ling pulls out a yellow pad and pen and starts taking notes. Go, girl! SADA Jones escalates it a step, even starts using some good witness interviewing technique:

SADA Jones: I'm sorry, Mr. Cliente, just so I'm sure I understand, would you mind going back over that part where you picked up the telephone and hit her with it-she was on the floor already at that point or..."

[Should I be letting him do this?? But the defendant's lawyer is right there, he's listening, nodding, even making little facilitative interjections like the ones the students learn to use when interviewing witnesses - "Sure, right" "So it was like that." He could, of course, stop his client from talking, from answering SADA Jones' questions, at any moment. Why on earth, what could be going through this man's mind?]

Finally, the defendant's narrative winds down. He actually seems somewhat relieved. He has just had, although he doesn't know it, as close as he's going to get to his day in court, and like almost everyone who becomes embroiled in the litigation process and finally gets to tell his own story to someone who ought to be able to translate it into justice, he feels better. He looks squarely, with some satisfaction, at his lawyer, at SADAs Ling and Jones, at me, obviously feeling vindicated, not remorseful or ashamed. His wife had misbehaved; she had disrespected him; he had taught her who was boss; she had foolishly involved the police; he had shown her what a mistake that 
had been; there should be no more problems. Now could we all just go home? $?^{30}$

SADA Ling: Okay, well, Mr. Cliente, that's really very helpful ... you know, I think, we could go ahead and get the case called and set the case down for trial, so you can get going back to work and all-

Mr. D: (Simultaneously, though in different tones) Trial-whaddya mean,

Mr. C: TRIAL?

Mr. D (continuing): Look, the man just told you, this was a onetime thing, his wife does not want to get involved, she's ashamed of her own behavior, she loves him and doesn't want him to lose his job, much less go to jail, she's never going to show up, you're never going to get your corrob, and-

SADA Ling: Well, actually, Mr. Defender, the complainant in this case has already signed a corroborating affidavit $t^{31}$ and the People are, in fact, ready for trial. (Opening her folder to pull out a copy of the corrob, just as we'd planned, albeit in a very different context.) Here's another copy for you, we did serve you by mail and file several weeks ago, and it's my understanding that the judge intends to preclude motions, so I think we need to work out a good trial date-

Mr. C: (Turning to Mr. D.) I don't understand what is going on here. Please-

Mr. D: Don't give me that-You know EXACTLY what's going on!" (Grabbing the corrob out of SADA Ling's hands.) That wife of yours, she must be feeding you some line-look at this-isn't this her signature? She's cooperating with the DAs all the way, it looks like. Buddy, you're in trouble. You better talk to this wife of yours, or-

30. Part of the important task of case planning that consumes so much of our time and effort in the Clinic involves identifying every possible scenario, both for the overall progress of the case and for each component event, and working out, like alternative chess games, the branched sequences of moves and countermoves. One of our most typical comments in feedback to the new SADAs is that they have focused on only one or two potential scenarios and have failed to prepare for several others. For once, however, I would not be faulting the two SADAs for not having anticipated this turn of events and figured out how to react. In fact, they are responding with considerably more aplomb than, at the moment, I could summon.

31. In New York, for a misdemeanor prosecution to proceed, the People must file an accusatory instrument that contains non-hearsay factual allegations which establish, if true, "every element of the offense charged and the defendant's commission thereof." N.Y. Crim. Proc. Law $\$ 100.40$ (1)(c) (McKinney 1992); see also id. $\S \S 100.15,170.10(4)(\mathrm{a}), 170.65$. Typically, in New York City, this is accomplished by having the victim of the crime read a misdemeanor complaint containing hearsay allegations by the arresting officer and "corroborate" those allegations by signing an affidavit to that effect, colloquially referred to as "the corrob." 
[At this point-as Mr. Defender starts advising his client to again violate the court's Order of Protection prohibiting any contact with the victim, and suggesting to him that the victim could terminate the prosecution - for safety reasons I will step in, without ambivalence. But just before I do, SADA Jones does, with astounding presence of mind, artfully speaking to the defendant without addressing him, even though by now it seems clear that his counsel has implicitly consented to our direct contact with his client.]

SADA Jones: Mr. Defender, I'm sure you realize that continuation of this prosecution has nothing to do with Ms. Victim. It's completely out of her hands; it's up to us. All this corroborating affidavit means is that she told the truth. She was asked to sign this by the police. Everything on this paper is the same, pretty much, as what your client has just said. And I know you don't mean to direct Mr. Cliente to violate the judge's order not to contact his wife, and to risk prosecution for a felony- ${ }^{32}$

There was more, but this is sufficient to convey the essence of the problem. Mr. Defender had just single-handedly converted a possible dismissal into an airtight case by inducing his client to provide the prosecution with a full confession, seemingly with the reckless abandon of a lawyer who had never spoken with his client about the case before turning us loose on him. In the process, he had also turned a flamethrower on any potential plea-bargaining bridges, including denigrating his adversaries as students and with a crude ethnic slur, and indicating his utter disdain for family violence prosecutions. We already knew that Mr. Defender didn't return our calls and didn't show up in court; it sounded as if he was equally unresponsive to his client's efforts to confer with him. Even in the lamentable conditions of New York City Criminal Court, where defendants like Mr. Cliente who, working at a minimum wage job, cannot afford private counsel and often receive suboptimal representation, Mr. Defender was well off the chart. What, if anything, did this mean for us as prosecutors?

As we headed back to the office after setting the case down for trial (without so much as a grumble from Mr. Defender about the court's preclusion of any pretrial motions as untimely), ${ }^{33}$ we began to talk about what had just happened. The students, as well as their supervisor, were still taking it all in.

32. As may be evident, one technique for trying to protect the victim of domestic violence from retaliation or other pressure to "drop charges" is emphasizing, whenever possible in the hearing of the defendant, that the victim's role is limited to that of a fact witness and that she cannot control the course of the prosecution.

33. See id. $\$ \S 255.10,255.20$ (mandating that all pre-trial motions be served within forty-five days after arraignment on the accusatory instrument). 
So, we suspended the afternoon's other planned business (the essence of clinical teaching is seizing the teachable moment ${ }^{34}$ ) to process the many inputs we had just received. On one level, there was the information from and about Mr. Cliente to absorb: out of his own mouth, with his lawyer standing by urging him on, ${ }^{35}$ he had just convicted himself not only of the original misdemeanor charge, but of violation of an outstanding court order of protection ${ }^{36}$ that quite possibly constituted an indictable felony. ${ }^{37}$ Even though people accused of family violence do tend to make inculpatory admissions because their lack of insight and sense of righteous superiority often make them eager to explain - not that they hadn't committed the charged conduct, but that their doing so was justified-even so, this extreme a version of the phenomenon didn't happen everyday.

On a second level, certainly our qualms about having reasonable cause to continue the prosecution ${ }^{38}$ had vanished. They had been

34. See, e.g., Fran Quigley, Seizing the Disorienting Moment: Adult Learning Theory and the Teaching of Social Justice in Law School Clinics, 2 Clinical L. Rev. 37, 39-44 (1995) (describing the efficacy of intense clinical experiences for teaching of values and ethical judgment).

35. The significance of this is, absent the attorney's consent, our direct questioning of Mr. Cliente would have: (1) constituted a stark violation of N.Y. Code, supra note 13 , DR 7-104 ("During the course of the representation of a client a lawyer shall not [c]ommunicate or cause another to communicate on the subject of the representation with a party the lawyer knows to be represented by a lawyer in that matter unless the lawyer has the prior consent of the lawyer representing such other party or is authorized by law to do so."); and (2) elicited no usable admissions because of the stringent rule prohibiting uncounseled questioning of represented defendants once a criminal proceeding has commenced. See Massiah v. United States, 377 U.S. 201, $205-$ 06 (1964) (holding that after commencement of a criminal action, questioning the defendant without counsel present violates the Sixth Amendment); People v. Samuels, 49 N.Y.2d 218, 222-23 (N.Y. 1980) (holding that after commencement of criminal action, any statements obtained from a defendant without a lawyer present are inadmissible, and that Miranda rights cannot be waived without assistance of counsel).

36. N.Y. Crim. Proc. Law $\S 530.12$ (McKinney 1992). An order of protection can be tailored to include various provisions; all orders prohibit threatening, harassing, assaulting, or intimidating the witness. In the family context, most "full" orders of protection also forbid the defendant to go near the witness and/or her children, or her home, place of business, church, the children's daycare center or school, etc. See Lee H. Elkins \& Jane Fosbinder, New York Law of Domestic Violence 751-69 (1998 \& 1999 Supp.)

37. Any violation of an order of protection is also a new, independent offense of contempt. Usually, it is a misdemeanor, but if it includes commission of another crime, such as assault or stalking or menacing, it is automatically elevated to a felony charge of criminal contempt in the first degree or aggravated criminal contempt. N.Y. Penal Law $\$ \S 215.51(b), 215.52$ (McKinney 1999); see also New York Law of Domestic Violence, supra note 36 , at 823-28.

38. See N.Y. Code, supra note 13, DR 7-103(A) ("A public prosecutor ... shall not institute or cause to be instituted criminal charges when he or she knows or it is obvious that the charges are not supported by probable cause."); see also ABA Standards for Criminal Justice Prosecution Function and Defense Function 3-3.9(a) (1993) ("A prosecutor should not institute, or cause to be instituted, or permit the continued pendency of criminal charges when the prosecutor knows that the charges 
replaced, however, with the far more puzzling quandary of what, if anything, we ought to do about Mr. Defender.

I wish that I could reproduce the dialogue in the office that afternoon as the two SADAs on the case first re-enacted, with verisimilitude, the incident in the corridor for their other SADA colleagues, and then talked and argued through the issues for several hours as a group. It was a classic example of the kind of experiential self-teaching, peer teaching, and teaching through supervision, that is so difficult to replicate in a classroom, whether by hypothetical or simulation. New lawyers who are introduced to comparable issues in the classroom (1) simply don't believe things like this happen, and view the hypothetical or simulation as an outlandish concoction of the fevered academic brain; and/or (2) assume or imagine the existence of much simpler solutions than in fact are available (e.g., "I would call his supervisor and ask to have another lawyer assigned to the case"as if such a request from a prosecutor might not be taken by a defense supervisor as grounds for accolade, not removal; as if the supervisor had a reservoir of spare lawyers; as if the 18-B Panel Administrator would be happy to oblige). One virtue of teaching through real cases is that it confronts the new lawyer with "you can't make this stuff up" issues, and precludes the facile resolutions that seem so alluring in the abstract and are so unattainable in reality. ${ }^{39}$

The task was to move beyond exclamations of disbelief and get the SADAs thinking analytically and systematically. Using our basic protocol for quality decision-making, we would start by identifying objectives; move on to brainstorming the broadest array of conceivable options; try to sort out the pros and cons of each option;

are not supported by probable cause [or] ... in the absence of sufficient admissible evidence to support a conviction.").

Most prosecutors describe this as the most difficult ethical responsibility they face because it entails an adjudicatory role that is not comfortable for most lawyers. For an impressive description of a prosecutor's reaching the painful conclusion that there was too great a risk that his robbery victim's identification of the defendant was mistaken, and therefore dismissing a very winnable case, see Kenneth J. Melilli, Prosecutorial Discretion in an Adversary System, 1992 BYU L. Rev. 669, 702 n.266. Note that one factor in Professor Melilli's decision to halt the prosecution was his concern about the caliber of the defendant's counsel.

39. See Steven Hartwell, Promoting Moral Development Through Experiential Teaching, 1 Clinical L. Rev. 505, 505-06 (1995); Ian Johnstone \& Mary Patricia Treuthart, Doing the Right Thing: An Overview of Teaching Professional Responsibility, 41 J. Legal Educ. 75, 92-95 (1991); David Luban \& Michael Millemann, Good Judgment: Ethics Teaching in Dark Times, 9 Geo. J. Legal Ethics 31, 50 (1995); see also Steven H. Leleiko, Love, Professional Responsibility, The Rule of Law, and Clinical Legal Education, 29 Clev. St. L. Rev. 641, 649-56 (1980); David A. J. Richards, Moral Theory, The Developmental Psychology of Ethical Autonomy and Professionalism, 31 J. Legal Educ. 359, $372-73$ (1981) (noting the importance of reciprocal role-playing in clinical and class settings to develop students' real legal experience and moral awareness). 
and make our choices. ${ }^{40}$ The first step led to some quick conclusions: we wanted to protect the complainant, who was clearly at risk from a man who believed that his exertion of control over her by physical violence and domination was legitimate; at the same time, we wanted to discharge our professional duty within the criminal justice system. Although no one in the group initially framed that duty as including a potential obligation to report Mr. Defender to any authority, there was discomfort and concern that an indigent defendant could be stuck with this lawyer.

\section{B. Was Mr. Defender Just Having a Bad Day?}

A good preliminary point was raised by one of the SADAs who wasn't on the case but had heard our description of the lawyer's behavior. Could it be that we had seen an aberration, that for whatever reason Mr. Defender had simply lost it today, that in the future (admittedly, after the horse had not just left but torn down the barn) he would revert to a vigilant guardian of his client's rights and interests? Without being sure that an affirmative answer would change the analysis, this SADA thought we needed more than a set of one event to justify almost any action we might undertake.

After all, every lawyer, the best and the most experienced, makes lots of mistakes. Because the raw material of our craft is basically human behavior, not organic tissue or inert matter, we are even more likely to commit harmful error than the physician or the engineer, both of whom make their fair share. A refreshing aspect of the long slow struggle that begins anew each year with each cadre of clinical students is assisting at the birth of their painful, humbling, yet ultimately relieved realization that even if they are as meticulous and methodical and insightful as we urge them to be, they are condemned to perpetrate untold numbers of serious mistakes-and that they are not alone. ${ }^{41}$

40. This variation on the scientific method, in the sense that generating and testing hypotheses are its constituent moves, is the template of the "problem-solving" or "clinical judgment" that many clinical teachers consider as our central educational objective. See Legal Education and Professional Development-An Educational Continuum, Report of the Task Force on Law Schools and the Profession: Narrowing the Gap, 1992 ABA Sec. Legal Educ. \& Admission to the Bar 141-51 (detailing the skills and concepts involved in problem-solving, including identifying and diagnosing a problem, generating alternative solutions and strategies, and developing a plan of action); Anthony G. Amsterdam, Clinical Legal Education-A 2Ist-Century Perspective, 34 J. Legal Educ. 612, 612-13 (1984) (describing systematic approach that ought to be taught in law school); see also Mark Neal Aaronson, We Ask You To Consider: Learning About Practical Judgment in Lawyering, 4 Clinical L. Rev. 247, 248 (1998) (discussing ways in which "professional judgment" is differentiated from "expert knowledge, systematic thinking, intuition, or common sense," and identifying the "core role of the lawyer" as a "problem solver;" defining the key curricular goal of clinics as fostering the development of good lawyering judgment).

41. The literature of confessed professional error has become abundant, but for 
From one isolated encounter, then, it might not be prudent to assume that Mr. Defender was as completely out-of-control and bereft of basic lawyering skills as he appeared to be.

Gathering additional information is generally an aspect of problemsolving that clinical teachers like to reinforce, and it took only a few probing questions (Who would be a reliable source on this? Who would be familiar with Mr. Defender's conduct in other cases at other times, for example?) to elicit the idea of e-mailing our colleagues within the DA's office to see whether anyone else could recall a notable experience with Mr. Defender. (Even before e-mail, institutional lawyers often used memos or scuttlebutt to check out office-wide perceptions of opposing witnesses and lawyers or judges.)

Typically, such an inquiry will garner three or four responsesmaybe six. In short order, we had three times that. Apparently, while my ADA co-teacher, who had been handling only felonies before starting in the Clinic, had been spared prior contact with $\mathrm{Mr}$. Defender, many other assistants hadn't been so lucky. The tales, even schematized for e-mail, were lurid and bizarre. Abuse of clients and utter non-responsiveness to attempts at contact were dominant themes. Phrases from staid ADAs like "the man is WILD!", "off on another planet," "shoots from the hip, usually at his own foot," suggested that our experience was far from unique. One ADA recalled Mr. Defender's arriving at his office and dropping off a client-"offering him up," as the ADA put it-to turn confidential informant in a fairly large drug case; the lawyer had not only left his client alone with the ADA, but, it soon became apparent, had not prepared or counseled the man about any of the implications, legal or practical, of providing information to be used against major drug lords.

None of these responses, however, indicated that any ADA had thought it proper or necessary to notify any authority about $\mathrm{Mr}$. Defender's conduct. No one mentioned having raised the issue of his competence with a judge presiding over one of his client's cases, or with the administrator responsible for his continuing representation of indigent defendants.

Now I want to switch gears away from the narrative and review the various issues, analyses, and sources of guidance that we considered along the way to our decision.

me, the classic of the genre is Dr. David Hilfiker's beautifully written volume, Healing the Wounds: A Physician Looks at His Work (1985). The most compelling chapter is Mistakes, a reprint of Facing Our Mistakes, a shockingly honest reflection on a number of errors in the doctor's own practice which seriously damaged patients, first published at 310 New Eng. J. Med. 118 (1984). 


\section{THE PROSECUTOR'S RESPONSIBILITIES WHEN DEFENSE COUNSEL IS INEFFECTIVE OR INCOMPETENT}

\section{A. Must a Prosecutor Intervene?}

In the earliest treatment of this issue that we could find, Professor Monroe Freedman, ${ }^{42}$ citing the example of an unlicensed defense counsel, seemed to take it for granted that a prosecutor must advise a trial court if, in the prosecutor's view, the defense lawyer is rendering ineffective assistance to the defendant. He does not, however, suggest what rule or rationale supports this assumption, and he does not suggest that mere incompetence would compel intervention. ${ }^{43}$ (At trial, of course, the judge is in about as good a position to detect the ineffective assistance as the prosecutor, although the latter might register some nuances that escape the judge.) However, Professor Freedman reports anecdotally that on the contrary, prosecutors concerned about a low level of defense counsel performance in a particular case deliberately insert praise of the defense lawyer's acumen into their summations, to insulate the resulting convictions from Sixth Amendment attack.

Not that, in general, prosecutors have much to fear from such an attack, as was so powerfully demonstrated in Judge David Bazelon's magnificent and still unmatched jeremiad on America's failure, at least in the criminal realm, to "assure that our adversary system of justice really is adversary and really does justice."

42. Howard Lichtenstein Distinguished Professor of Legal Ethics at Hofstra Law School, and one of the most formidable scholars in the field of legal ethics.

43. Monroe H. Freedman, Lawyers' Ethics in an Adversary System 89 (1975); published in an earlier version as Monroe H. Freedman, The Professional Responsibility of the Prosecuting Attorney, 55 Geo. L.J. 1030, 1039-40 (1967).

44. David L. Bazelon, The Defective Assistance of Counsel, 42 U. Cin. L. Rev. 1, 2 (1973) (For the younger readers, Judge Bazelon was Chief Judge of the United States Court of Appeals for the District of Columbia and an extraordinary visionary about the need for procedural safeguards, including especially competent, well-trained lawyers with adequate resources to protect the rights of the poor, the mentally compromised, and other disadvantaged people). This article evoked much controversy when published because it was one of the first, and remains one of the most powerful, condemnations of the quality of counsel provided to poor people by the assigned counsel system - and I think it worth quoting at length, because in my opinion, absolutely no one has ever put it better. Judge Bazelon, reporting the coinage of a phrase that has become part of the common currency of discourse about criminal justice:

The adversary system assumes that each side has adequate counsel. This assumption probably holds true for giant corporations or well-to-do individuals, but what I have seen in 23 years on the bench leads me to believe that a great many-if not most-indigent defendants do not receive the effective assistance of counsel guaranteed them by the 6 th Amendment.... There are no statistics to illustrate the scope of the problem because, as I shall demonstrate, the criminal justice system goes to considerable lengths to bury the problem. But no one could seriously 
Judge Bazelon devotes only a page to the prosecutor's contribution to the prevalence of the "defective assistance of counsel." 45 He sees no incentives for a prosecutor to refrain from taking advantage of the widespread gross inadequacies of appointed defense lawyers, noting that given the paucity of reversals of conviction on such grounds, prosecutors are not likely to "think twice." 46

The next analysis we located is a two-page discussion in Professor Fisher's major article, In Search of the Virtuous Prosecutor. ${ }^{47}$ Professor Fisher posits the hypothetical of the "incompetent defense counsel" who betrays, in the course of plea bargaining, apparent unawareness of a strong suppression issue that might lead to dismissal (interestingly enough, based on experience with a clinical law student placed in a prosecutor's office).$^{48} \mathrm{He}$ points out that "[p]rosecutors are uniquely positioned to observe incompetent and lazy representation of defendants," 49 and asks, "Should the prosecutor... inform the authorities of [defense counsel's] incompetence?"50 His response is, in essence, that the answer is unclear. He seems inclined

dispute that ineffective assistance is a common phenomenon. A very able trial judge described some of the counsel coming before the courts as "walking violations of the sixth amendment."

....

Much like the provision of medical care to the poor, the provision of legal counsel to the indigent is a non-prestigious activity that the public and the profession would rather not think about. Just as we assume our medical responsibility is met when we provide poor people a hospital, no matter how shabby, undermanned and underfunded, so we pretend to do justice by providing an indigent defendant with a lawyer, no matter how Id. at 4 . inexperienced, incompetent or indifferent.

Judge Bazelon then describes some classic cases, including the defense lawyer who didn't know that courts maintain records of prior convictions; the one who told the judge he'd sum up in ten minutes to avoid getting a parking ticket; the lawyer who spent all of fifteen minutes with his client before pleading him guilty to a capital offense, despite the client's claim of exculpatory witnesses; the trial counsel who met the client for the first time on the way to court on the morning of trial and had "virtually no acquaintance" with the facts of the case; and, of course, the renowned case of the lawyer who slept soundly through the examination of the prosecution witnesses. Id. at $2-3,11,21,30$. He also presents the various archetypes of defective counsel, including the "regulars," the "sweetheart" lawyers who depend on judges for continued appointments and a high volume of modest fees, and who try to oblige the judges by "moving along" their crowded calendars with no motions, no investigations, and quick pleas; the "uptown lawyers" who are clueless and unenthusiastic about criminal practice but, with distaste, accept a defense appointment as a matter of duty; and the neophytes trying their first cases who "not only [don't] know what to do next; [they don't] know what to do first." Id. at 7-16.

45. Id. at $14-15$.

46. $I d$.

47. Stanley Z. Fisher, In Search of the Virtuous Prosecutor: A Conceptual Framework, 15 Am J. Crim. L. 197, 222-23 (1988).

48. Id.

49. Id. at 222.

50. Id. at 222 n.124. 
to consider more seriously the possibility of trying to "compensate" for the defender's limitations by, e.g., alerting him to the Fourth Amendment problem than by reporting the malfeasance.

Writing a year after Professor Fisher, another important commentator with real prosecutorial experience, Professor Bruce Green, concludes that prosecutors ought to become their "brother's keepers" when confronted with the situation of the defense lawyer who may have conflicting interests in the representation of a particular defendant. ${ }^{51}$ Using four illustrative cases in which courts instructed prosecutors to intervene, Professor Green cogently reasons that the prosecutor's obligation to "do justice" entails a responsibility "to ensure that a criminal defendant is not unjustly convicted and that the proceedings leading up to a conviction are fair," 52 and that an independent, conflict-free lawyer is a necessary element of a fair proceeding as well as a specific right guaranteed by the Sixth Amendment promise of the assistance of counsel. ${ }^{53} \mathrm{He}$ also seizes on a correlative aspect of the prosecutor's role-the "administrator of justice" - as the locus of an "affirmative responsibility to promote the orderly, efficient administration of criminal justice," including "a duty to avoid missteps that will result in reversals of criminal convictions and necessitate retrials." $54 \mathrm{He}$ has no trouble finding a broad duty to advise both defense counsel and the trial court of perceived or potential conflicts, such as a defense lawyer's having previously represented a prosecution witness, ${ }^{55}$ or being accused of wrong-doing by a prosecution witness. ${ }^{56}$ Even when the defense lawyer is well aware of the potential problem, and presumably has taken appropriate steps to address it, Professor Green declares that the prosecutor must still alert the trial court, and may even be required to file a formal disqualification motion to ensure that the court will give it sufficient attention and that the defendant will be properly advised of the potential ramifications of the defense lawyer's continuing representation..$^{57}$

Professor Green deals only briefly with the situation in which the defense lawyer is compromised in ability or zeal rather than integrity. ${ }^{58}$ "[W] $[\mathrm{W}$ hen it becomes apparent that defense counsel may be

51. Green, Her Brother's Keeper, supra note 18, at 365.

52. Id at 324.

53. Id. at 341 ("The right to counsel prevents the State from conducting trials at which persons who face incarceration must defend themselves without adequate legal assistance." (quoting Cuyler v. Sullivan, 446 U.S. 335, 344 (1980))).

54. Id. at 325 .

55. Id. at 332-38 (discussing, for example, United States v. Mitchell, 572 F. Supp. 709 (N.D. Cal. 1983)).

56. Id. at 338-45 (discussing, for example, Mannhalt v. Reed, 847 F.2d 576 (9th Cir. 1988)).

57. Id. at $365-66$.

58. See id. at 341-42. 
denying the accused adequate legal assistance, the prosecutor, as a representative of the State, should take reasonably available steps to remedy the problem." 59 As Professor Green observes, such an obligation cannot be grounded in anything explicit in either of the major ethical codes. However, he does quote the far less authoritative American Lawyer's Code of Conduct: "A lawyer serving as public prosecutor, who knows that a defendant is not receiving or has not received effective assistance of counsel, shall promptly advise the court, on the record when possible" 100 and cites language from one of the first ineffective assistance opinions about the "duty of the ... prosecution to observe... and correct [ineffective representation]." 61 Again, as in Professor Freedman's article, Professor Green's focus is on the need to act when defense counsel is constitutionally ineffective, rather than merely incompetent.

The strongest case for the prosecutor's duty to intervene after recognizing incompetence on the part of defense counsel is made by Professor Fred Zacharias in his comprehensive article, Structuring the Ethics of Prosecutorial Trial Practice. ${ }^{62}$ Professor Zacharias views the lazy, or temporarily incapacitated, or generally incompetent, or grossly unprepared defense lawyer as a potentially fatal defect in the truth-producing machine of the adversary system more than as an abrogation of the Sixth Amendment rights of a defendant. ${ }^{63}$ Instead of using ineffective assistance as the threshold for intervention, Professor Zacharias identifies a working adversarial system as the sine qua non of the "justice" that prosecutors are sworn to uphold. That, in turn, presumes something like a level playing field for the government and the defendant in terms of the quality of their attorneys and other resources. ${ }^{64}$

Professor Zacharias does an excellent job of explaining why the theoretical guarantees of a level playing field are far from reliable. Market forces simply have no place in this realm; the vast majority of criminal defendants have zero capacity, either in liquid assets or in life

59. Id.

60. Id. at 342 n.79.

61. Id. citing Diggs v. Welch, 148 F.2d 667, 670 (D.C. Cir.), cert. denied, 325 U.S. 889 (1945) (defining the "absence of effective representation [i.e., ineffective assistance of counsel]" as "representation so lacking in competence that it becomes the duty of the court or the prosecution to observe it and correct it"); see also In re Wolfram, 847 P.2d 94, 104-06 (Ariz. 1993) (Martone, J., concurring) (stating that the trial judge and prosecutor had duty to report inadequate representation of criminal defense counsel to disciplinary authorities (citing Arizona equivalent of DR 1-103(A), but with no discussion or other authority)).

62. Zacharias, Structuring the Ethics, supra note 18; see also Fred C. Zacharias, Justice in Plea Bargaining, 39 Wm. \& Mary L. Rev. 1121, 1164-76 (1998) [hereinafter Zacharias, Justice in Plea Bargaining].

63. Zacharias, Structuring the Ethics, supra note 18.

64. Id. at 61. 
skills, for selecting and retaining competent counsel..s Judicial oversight, in theory the preferable alternative to prosecutorial intervention, cannot be relied upon both because the dwindling supply of willing counsel tends to limit judicial choice when it comes to appointment or suspension of eligibility for appointment, ${ }^{\infty}$ and because too many judges, consciously or subliminally, prefer the less aggressive advocate who cooperates in disposing of cases and helping to clear the judge's docket. ${ }^{67}$ Appellate courts, as Professor Zacharias explains, demonstrate an "institutional reluctance" $\$$ to reverse convictions for ineffective assistance, which requires the convicted defendant to meet an almost impossible standard. ${ }^{\text {ty }}$ Moreover,

65. Some of the private lawyers who command the highest fees are among the worst. Professor Zacharias does not really address whether and how the dynamics of the prosecutor's duty vis-a-vis an appalling privately retained attorney would change, but given the minuscule proportion such lawyers constitute of the defense bar, it is hardly a gaping hole in his analysis. Cf. Cuyler v. Sullivan, 446 U.S. 335, 343-45 (1980) (holding that constitutional sufficiency of legal assistance provided by retained counsel in criminal case must be measured by the same standard applied to representation by court-appointed counsel).

66. In some jurisdictions, like the City of New York, fewer and fewer altorneys are willing to accept appointment as defense counsel, and there is little reason to think that those who do constitute the flower of the defense bar. The refusal of the New York State Governor and Legislature for over fourteen years to increase the remuneration for appointed defense counsel from the absurd level of $\$ 40$ per hour for in-court time and $\$ 25$ per hour for out-of-court work is blamed for the unavailability of appointed counsel to handle "conflict" and other cases that cannot be handled by the institutional defenders, such as the Legal Aid Society or Manhattan Defenders. "A crisis exists in our criminal and family courts, resulting from the entirely inadequate compensation that assigned counsel are paid," according to Deputy Chief Administrative Judge for Justice Initiatives of the New York Unified Court System Juanita Bing Newton. John Caher, No Move to Raise 18-B Rates Expected from Albany, N.Y. L.J., June 7, 2000, at 1. Even the president-elect of the New York State District Attorneys Association supports increasing the level of compensation, noting that convictions could be overturned and new trials required because of valid ineffective assistance of counsel claims. Id.; see also Def.'s Supplemental Mem. in Supp. of Mot. to Dismiss, N.Y. County Lawyers' Ass'n v. Pataki, (No. 102987/00) (N.Y. Sup. Ct.) [hereinafter Def.'s Supplemental Mem.] (pleadings on file with the author) (presenting a novel civil action alleging deprivation of the Sixth Amendment right to counsel because of the inadequate compensation offered to court-appointed criminal defense lawyers and consequent mass defection of high-quality lawyers from the appointment panel).

67. See Zacharias, Structuring the Ethics, supra note 18, at 66-67.

68. Id. at 67.

69. Merely establishing that the defense lawyer failed to provide minimally acceptable representation is not sufficient. The defendant must show that, but for the substandard representation, there is at least a "reasonable probability that ... the result ... would have been different." Strickland v. Washington, 466 U.S. 668, 694 (1984).

This standard focuses not on whether the defense counsel was minimally competent, or performed the basic functions contemplated by the Sixth Amendment guarantee of counsel in criminal cases, but instead on what the Supreme Court deems the threshold question of the defendant's factual guilt. Assuming that the evidentiary record supporting a finding of guilt would not be significantly different had an effective defense lawyer been on the case-an indefensible assumption-reviewing 
obtaining relief on appeal is hardly a substitute for justice at the trial level, given the impacts on family, job, etc. of a criminal conviction, the distinct likelihood of serving all or most of a sentence before an appeal is decided, and the disadvantage of facing a retrial long after

courts have countenanced hideous and ludicrous travesties of lawyering. See Martin C. Calhoun, Note, How to Thread the Needle: Toward a Checklist-Based Standard for Evaluating Ineffective Assistance of Counsel Claims, 77 Geo. L.J. 413, 425-32 (1988). In a survey of all federal ineffective assistance claims reviewed by circuit courts between the Strickland decision in 1984 and May 1988, it was found that counsel's performance was "professionally reasonable" in only $54.3 \%$ of the cases; however, only $4.3 \%$ of the cases resulted in reversals because pursuant to Strickland, courts first had to find "prejudice," i.e., that the result was not "just." Id. at 430-31. In effect, Strickland means that the "factually guilty" defendant does not deserve the same right to effective assistance of counsel as the "innocent" defendant. Id. at 428-30.

Even lawyers who have been disbarred or suspended because of their incapacitation while representing a defendant are nonetheless deemed effective. See Timothy J. Lucey, Comment, Bellamy v. Cogdell: The Ethical Implications of Claims of Ineffective Assistance of Counsel, 6 Geo. J. Legal Ethics 549, 550-51 (1993). The Second Circuit refused to reverse a conviction on ineffective assistance grounds despite the fact that defense counsel, who had come out of retirement to conduct the criminal trial, was simultaneously charged with disciplinary violations, and had responded by seeking lengthy adjournment of the disciplinary hearing because health problems "incapacitated" him. Id. at 561-62. Counsel had also promised to associate a "competent attorney" to assist him in the trial if the court would delay his suspension from practice until after the trial. Counsel, however, never informed the defendant of the pending disciplinary charges, his admitted incapacity, or his promise not to try the case by himself, but proceeded to try the case without co-counsel. He was suspended two months later. The trial judge held a post-conviction hearing on the ineffective assistance claim, but refused to require the defense lawyer to testify, and sustained the verdict. Id.; accord State v. Green, 643 A.2d 18, 20 (N.J. Super. Ct. App. Div. 1994) (holding no ineffective assistance when lawyer conducted trial while suspended and suffering from alcohol and drug dependency leading to lawyer's arrest for possession of cocaine just after verdict); Commonwealth v. Vance, $546 \mathrm{~A} .2 \mathrm{~d} 632$, 637-39 (Pa. Super. Ct. 1988) (holding no ineffective assistance when attorney was disbarred two months after defendant pleaded guilty, and also had been using cocaine during the representation); see also United States v. Mouzin, 785 F.2d 682, 696-98 (9th Cir. 1986) (holding that disbarment during trial does not constitute ineffective assistance); United States v. Dumas, 796 F. Supp. 42, 46-47 (D. Mass. 1992) (indicating that representation at trial by "lawyer" who had never been admitted in the jurisdiction (although once admitted in a different state) and who conducted unauthorized practice for almost eleven years, using fabricated registration numbers for papers filed in federal court, does not constitute ineffective assistance under the Strickland test); People v. Allen, 580 N.E.2d 1291, 1300-01 (Ill. App. Ct. 1991) (holding that pending disbarment during trial, and disbarment before post-trial hearings, did not constitute ineffective assistance); State v. Smith, 476 N.W.2d 511, 513 (Minn. 1991) (maintaining that suspension of counsel is not equivalent to ineffective assistance).

This is one societal injustice that legal scholars have well and truly documented. See, e.g., a trilogy of devastating articles by Touro Law Professor Richard Klein: The Emperor Gideon Has No Clothes: The Empty Promise of the Constitutional Right to Effective Assistance of Counsel, 13 Hastings Const. L.Q. 625 (1986) [hereinafter Klein, The Emperor Gideon Has No Clothes]; The Relationship of the Court and Defense Counsel, supra note 11; The Eleventh Commandment: Thou Shalt Not be Compelled to Render the Ineffective Assistance of Counsel, 68 Ind. L.J. 363 (1993); see also Bruce A. Green, Lethal Fiction: The Meaning of "Counsel" in the Sixth Amendment, 78 Iowa L. Rev. 433 (1993). 
the offense. (Despite the general view that prosecutors suffer and defendants profit from delay, it can be problematic for a defense case too.) As Professor Zacharias notes, "[r]eacting to incompetent defense representation before a verdict is rendered may preserve the integrity of the trial process in a way that appeals cannot."

In discussing slightly less egregious cases - where "[d]efense counsel performs, but very badly," or appears to perform well, but to the prosecutor's uniquely sensitive eye, is missing important tactical opportunities $^{71}$ - Professor Zacharias seems ambivalent. He strains to show that even the latter category might, under rare circumstances, be considered ineffective assistance. ${ }^{72}$ From Professor Zacharias' discussion, it is not entirely clear whether he would invoke the prosecutor's duty to act: (1) whenever the representation is insufficiently adversarial in the prosecutor's view; or (2) instead, only when it is atrocious enough to conform with the caselaw's definition of ineffective assistance.

Initially, Professor Zacharias uses phrases like a lack of "building blocks of the adversary system" and "valid competitive adjudication" to describe the kind of problem that requires prosecutorial rectification. ${ }^{73} \mathrm{He}$ suggests that the prosecutor's "duty to step out of the advocate's role" to "help restore adversarial balance" is triggered whenever a defendant is deprived of "what constitutes a fair trial: one in which an innocent defendant has a full opportunity for vindication...."74 (I think the meaning here is not that this very defendant must be factually "innocent," in the sense that Strickland seems to demand Sixth Amendment-compliant representation only for the innocent, but rather that the quality of the representation should be high enough to enable this defendant, IF innocent, to escape conviction.) Later, Professor Zacharias describes the breakdown of adversarial justice "when a criminal defense attorney

70. Zacharias, Structuring the Ethics, supra note 18, at 69.

71. Even more imperative is intervening to "level the playing field" between prosecutor and ineffective/incompetent defense counsel prior to trial or when no trial is contemplated, i.e. in plea bargaining. See Zacharias, Justice in Plea Bargaining, supra note 62. In this later article, Professor Zacharias juxtaposes a variety of theoretical rationales for prosecutorial plea offers. Some of these theories could permit the prosecutor to take full advantage of defense counsel's lapses; others would allow a prosecutor to offer only the plea that a fully informed, uncoerced, wellrepresented defendant would be offered. Surprisingly, Professor Zacharias acknowledges with some sympathy the distaste prosecutors feel for having to report an ineffective defender to the court, and suggests ways to avoid this duty, e.g. by offering a deal that is "too good for the defendant" to pass up. Id. at 1169. In any event, reliance on disclosure to the court as a remedy seems self-contradictory given Professor Zacharias' description of the court's limited options upon disclosure. See infra note 85.

72. Id at 70 n.111.

73. Id. at 61-62.

74. Id. at 64-65. 
does not even roughly match the prosecutor's talents or fails to represent his client's interests" as "a one-sided contest."75

All of these formulations of the "trigger" for prosecutorial action amount to a far cry from the "eye of the needle" test, ${ }^{76}$ and suggests that it would take less abysmal failure by a defense lawyer, in Professor Zacharias' view, to invoke the prosecutor's duty to intervene than it would to reverse a conviction. Yet, ultimately he seems to accept the notion that as long as the defense lawyer stays within "the wide range of professionally competent assistance,"-i.e., if the representation is not bad enough to warrant reversal-the prosecutor has no reason, and no responsibility, to act at all. ${ }^{77}$ It is only in regard to the most obvious case-when the presiding judge either is or chooses to be unaware of the defense counsel's deficiencies, and those deficiencies are plainly of a magnitude that amounts to "essentially no representation" (e.g., the drunk, senile, or clueless defender) that Professor Zacharias suggests action is required.$^{78}$ Because of the prosecutor's inherent role in the criminal justice process, her duty "to do justice," she cannot "passively accept systemically faulty outcomes;" 79 rather, the prosecutor must consider "whether she is in a unique position to perceive and remedy the systemic breakdown before a one-sided trial results" ${ }^{80}$ and, if so, she must "undertake remedial steps." 1

Professor Zacharias describes a range of these "steps." One could attempt to restore the adversarial balance of power either by pulling some prosecutorial punches - which would only render the proceeding less adversarial, not more fairly so-or through outright assistance to the defendant by mustering favorable evidence or raising neglected issues. This approach, Professor Zacharias fears, would be logistically cumbersome and unfairly detrimental to the effective and logical presentation of the People's case. Defense counsel's limitations might not surface until after the People's direct case; only then would the failed cross-examination or forgone defense case become evident, and it would seem strange and confusing for the prosecutor to devote the crucial final stage of trial-her rebuttal-to highlighting sources of reasonable doubt. Moreover, over time, defense lawyers who caught on to this potential windfall of positive evidence at the end of the case would be induced to refrain from cross-examination or presenting

75. Id. at 66 .

76. Calhoun, supra note 69.

77. Zacharias, Structuring the Ethics, supra note 18, at 69 (quoting Strickland v. Washington, 466 U.S. 668, 690 (1984)).

78. Id. at 68-69. Professor Zacharias also points out that in every contest of two, it's to be expected that one or the other is or will appear to be somewhat less talented or active, that absolute equality of adversaries is never achieved. Id. at 68 .

79. Id. at 64 .

80. Id. at 70 .

81. Id. at 69. 
their defense, knowing that it would ring far more persuasively to the fact-finder if it came from the prosecution. ${ }^{22}$

No, Professor Zacharias suggests a different sequence of intervention. First, the prosecutor might deliver some comradely admonitions to the defense lawyer, telling him to pull up his socks and do better for his client, or else withdraw. If that is not efficaciousand, in all honesty, it's hard to envision a really bad defense lawyer's radical improvement from such a conversation, nor a trial judge's happily acceding to that lawyer's motion to withdraw because the prosecutor says "The defense lawyer's not doing a good enough job for the defendant" 83 - then the prosecutor must try to force the issue

82. Id. at 71. I actually find this projected trajectory of "moral hazard" rather farfetched. Unless the prosecutor or the defense lawyer shows up in the case only at the start of trial, with no prior contact with the adversary, it would be surprising if such gross defects in the defendant's representation went undetected throughout prior proceedings-proceedings that would most likely culminate in a plea, not a trial. The prosecutor, therefore, would in reality have reason to know the trial would not be adequately adversarial much earlier on.

Moreover, in my judgment, it would take a long, long, long time before most defense counsel clever enough to anticipate and try to take advantage of a prosecutor's feeling compelled to offer evidence favorable to the defense in rebuttal would bank on it. Erratic as the quality of representation for the indigent defendant is, I doubt there are enough bad defense lawyers out there, and I'm sure there are not enough prosecutors who see rectifying their errors as an aspect of the mission "to do justice", for one of each to coincide on the already statistically rare event of a trial. Also, this scenario would have to recur very, very frequently before any semicompetent defense attorney would hold back on viable arguments or evidence just to trap the prosecutor into offering them.

83. The reported opinions on ineffective assistance are replete with examples of lawyers pleading with trial judges, fruitlessly, to be relieved from criminal defense appointments because the lawyers knew that they were or would be in stark violation of DR 6-101(A)(1). See N.Y. Code, supra note 13, DR 6-101(A)(1) ("A lawyer shall not: handle a legal matter which he knows or should know that he is not competent to handle."); see also Model Rules of Profl Conduct R. 1.1 (1983) (hereinafter Model Rules] ("A lawyer shall provide competent representation to a client. Competent representation requires the legal knowledge, skill, thoroughness and preparation reasonably necessary for the representation."). See, e.g., Aldrich v. Wainwright, 777 F.2d 630, 633 (11th Cir. 1985) (holding that continuance will not be granted even though counsel stated that he was "totally unprepared" and not in a position to provide competent legal representation; as a result, defendant convicted and sentenced to death); Dillon v. Duckworth, 751 F.2d 895, 897 (7th Cir. 1984) (upholding conviction and death sentence of defendant despite trial court's denial of defense lawyer's request for continuance of murder trial because of his inability to prepare due to three major life crises-his father's heart surgery, his brother's paralysis, and his own divorce-in the preceding three months; counsel had been ordered to proceed even though he had spent less than four hours with defendant); United States v. Ruiz, 533 F.2d 939, 939-40 (5th Cir. 1976) (refusing to grant continuance or withdrawal even though counsel had been arrested on an extradition warrant during trial, and had requested continuance after release because he was in "emotional shambles" and could not proceed); United States v. Ploeger, 428 F.2d 1204, 1205 (6th Cir. 1970) (upholding conviction and twenty-year sentence of defendant after one-day trial, although lawyer had been ordered to trial on his first day of appearance in the case, and had told the judge that he had never seen the indictment, investigated, nor prepared the case); Wood v. Superior Court, 690 P.2d 
on the trial judge, either by "simply ... telling the judge" or with a formal motion to disqualify. ${ }^{84}$

And then what? Professor Zacharias anticipates that the "practice of reporting inadequate performance would have beneficial effects for defendants" by both alerting the defendant to his counsel's failings and enabling the trial judge to remedy the otherwise "hidden

1225 (1984), overruled in part on other grounds, DeLisio v. Alaska Superior Court, 740 P.2d 437 (Alaska 1987); see also Stern v. County Court, 773 P.2d 1074, 1080 (Colo. 1989) (holding that an attorney appointed to represent a criminal defendant who believes that he or she is incompetent to handle the case bears the burden of proving that incompetence to the court); State v. Wilson, 687 P.2d 800, 802-03 (Or. Ct. App. 1984) (denying defense counsel's request to withdraw from the case, despite his contention that he could not adequately defend his client because he was intimidated by the trial judge); In re J. R. C., 593 S.W.2d 124, 124-25 (Tex. App. 1979) (finding that lower court properly denied counsel's request to withdraw due to his lack of experience and familiarity with criminal trials); $c f$. Easley v. State, 334 So. 2d 630, 632 (Fla. Dist. Ct. App. 1976) (granting on reconsideration an initial denial of motion to withdraw in felony case, but holding lawyer in contempt and fining him $\$ 500$ for informing defendant that he felt incompetent to provide representation); see generally Annotation, Ineffective Assistance of Counsel: Right of Attorney to Withdraw, as Appointed Defense Counsel, Due to Self-Avowed Incompetence, 16 A.L.R.5th 118 (1993 \& Supp. 2000).

There is no indication in any of these cases that the prosecutor opposed the appointed counsel's application to withdraw, but these judges nonetheless insisted that counsel proceed. Apparently, it is a "widely-held concern" of the bench that some defense lawyers are so zealous and self-sacrificing that they will feign "ineffectiveness" as part of a deliberate stratagem to "throw" the case in order to create an ineffectiveness issue on appeal. See People v. Sullivan, 550 N.Y.S.2d 358, 361 (App. Div. 1990) (holding lawyer's misconduct in disparaging murder victims during summation "in terms which any decent person would find offensive"suggesting that they were "unsavory moral degenerates who... deserved to die"must have been a trial tactic, albeit "desperate" and "reckless;" even if this tactic were undertaken without defendant's knowledge or consent, still not ineffective assistance). To me, it seems a bit far-fetched to fear that lawyers would happily proclaim themselves incompetent in order to infect the record with reversible error and assist obviously guilty defendants who are paying them nothing.

Nor is the refusal to relieve lawyers who confess incompetence a problem confined to individual court-appointed counsel. With equal lack of success, institutional and public defenders have tried to seek relief from further appointments by asserting that wildly excessive caseloads, insufficient training and resources, etc., make them unable to offer representation that constitutes "preparation adequate in the circumstances." See N.Y. Code, supra note 13, DR 6-101(A)(2)-(3); see also Model Rules, supra R. $1.1,1.3$ ("thoroughness and preparation reasonably necessary for the representation"; "reasonable diligence and promptness in representing a client"). See Klein, The Relationship of the Court and Defense Counsel, supra note 11, at 540-48; Rebecca Marcus, Note, Racism in Our Courts: The Underfunding of Public Defenders and Its Disproportionate Impact Upon Racial Minorities, 22 Hastings Const. L.Q. 219, 230-37 (1994).

Ironically, lawyers who seek relief from court appointment to represent the indigent on civil matters enjoy an absolute right to withdraw for any reason or no reason. See Mallard v. United States Dist. Court for the S. Dist. of Iowa, 490 U.S. 296 (1989). They can even mandamus the judge! A heady thought for any erstwhile criminal defense lawyer. Id. at 309, 316.

84. Zacharias, Structuring the Ethics, supra note 18, at 72. 
ineffectiveness" by replacing or supplementing the failing lawyer ${ }^{85} \mathrm{At}$ a minimum, the trial judge would have to conduct a hearing on the issue, which should provide a far fuller record on appeal than is typically available to the ineffectively-assisted appellant. ${ }^{86}$

At this point, I have to try to translate this seductive scenario back to 100 Centre Street. What is the probable reaction of the defense lawyer? Most of the terrible defense lawyers, whether from Legal Aid, a contract defender, or 18-B, are there because it's the best option they have-in that sense, because they choose to be. The lawyers still working at 100 Centre Street are largely divided between 1 ) the conscientious and dedicated who feel compelled to try to meet the desperate need for competent representation, and 2) the dregs who can't drum up enough private business or find another salaried job. In other jurisdictions and settings, lawyers may be dragooned into criminal court and assigned cases, but in New York City, that is exceedingly rare. So, there is little reason to anticipate the bad defense lawyer's seizing on the prosecutor's allegations of incompetence as a way out of a case.

On the contrary, wouldn't we expect their intense resistance to being labeled as not just less-than-topnotch, but as so patently, grotesquely incompetent as to fall below the low, low threshold for effective assistance, or at least, in Professor Zacharias' phrase, "lax opposition"? ${ }^{87}$ Even if the lawyer wanted off the case for any of a number of reasons, such as distaste for the defendant or the crime, once the issue is framed as representation so poor as to be unconstitutional, what defense lawyer will meekly concede? While assuredly quality control among the institutional defenders is not all that it should be, removal from even one case on this basis could spark some inquiry, and if repeated, eventually might lead to the offender's loss of employment or panel membership. That, of course, is exactly what we would hope for, but the defense lawyer is not likely to go quietly.

Perhaps, as Professor Zacharias suggests, through a fact-finding hearing or in-court colloquy, the defendant will learn of the prosecutor's concern. ${ }^{88}$ If so, what will the defendant make of it? If

85. Id. at 73. Yet doesn't this reliance on the court seem misplaced in light of Professor Zacharias' analysis, a few pages before, of the limited options in the way of substitute counsel available to the court? See supra notes 65-67 and accompanying text. Again, even when defense counsel proclaim their incompetence to a court, judges not merely allow but force them to continue representation in stark violation of the defendant's Sixth Amendment rights. See supra note 83. So why assume that making the judge aware of counsel's deficiencies will accomplish much?

86. Id at 73-74.

87. Id. at 74 .

88. Or then again, perhaps not. See Bellamy v. Cogdell, 952 F.2d $626,628-29$ (2d Cir. 1991) (discussing trial judge's failure to advise the defendant prior to trial of pending disciplinary charges against his attorney or attorney's admitted incapacity). 
the defendant already has misgivings about the zeal or skill of counsel, will those misgivings be confirmed or confused by the arch-enemy's red flag? If, as seems all too likely based on the cool reception judges accord post-conviction and appellate claims of ineffective assistance, counsel is not replaced, what will have been accomplished? Will this airing of the situation make the defense lawyer shape up and fly right? Will it allay or exacerbate the defendant's concerns? If the judge ultimately replaces counsel, and (just for argument's sake) the new lawyer determines that the defendant would be best served by trying to work out the best deal possible, will the defendant wonder whether this was all a clever ruse to obtain a guilty plea?

Do we really have reason to believe that even if the original defense counsel is replaced, it will be by a more talented or dedicated or knowledgeable defender? It's impossible to give odds, but we do know that more and more of that type of lawyer are leaving this practice, in part because of the lack of compensation. ${ }^{89}$

According to these analyses, we certainly had a substantial basis to conclude that if we were convinced that the quality of Mr. Defender's representation fell below the standard of ineffective assistance of counsel, we ought to intervene. But what if we concluded that $\mathrm{Mr}$. Defender was merely "incompetent", in terms of the Code/Rules requirement of competence, but not "ineffective" as Sixth Amendment jurisprudence has defined that term? Did we have a responsibility to act even if Mr. Defender's representation managed to pass constitutional muster?

All of the authorities that had addressed the issue seem to suggest that prosecutorial intervention is not required absent a constitutional violation, although it might well be warranted. The judicial decisions on ineffective assistance of counsel indicate that Mr. Defender's conduct, damaging as it had been, technically did not rise (or sink?) to the standard of a constitutional violation. After all, Mr. Cliente had told us himself that he was guilty, with the warm body of his licensed lawyer standing by. The Sixth Amendment, according to the Supreme Court and the Second Circuit, had been satisfied because no matter what happened to Mr. Cliente, it could hardly be an "unjust" outcome. ${ }^{90}$ Nor would New York State's standard for the right to counsel- "meaningful representation"-require much more. ${ }^{91}$

89. See supra note 66; see also Def.'s Supplemental Mem., supra note 66.

90. Strickland's required showing of a "reasonable probability that, absent the errors, the factfinder would have had a reasonable doubt respecting guilt" is virtually impossible to establish when the defendant is factually guilty. The Supreme Court said that only the defendant who can show that otherwise he may have been acquitted is entilled to a remedy for ineffective assistance. Strickland v. Washington, 466 U.S. 668, 695 (1984); see also Hill v. Lockhart, 474 U.S. 52, 59 (1985) (finding that when defendant's lawyer misinformed defendant about length of minimum sentence prior to entry of negotiated plea for that sentence, the defendant must show a "reasonable probability" that he would have instead gone to trial and been acquitted); see also 
We found ourselves still in the realm of discretion, so far as our duty to "justice" and the adversary system is concerned.

\section{B. Even if the Prosecutorial Duty to "Seek Justice" Does Not Require Intervention, Are Prosecutors Required by DR 1-103(A)/M.R. 8.3 to Report Incompetent Defense Counsel?}

The issue that confronted us has, as noted above, rarely been characterized as a specific issue of prosecutorial ethics. It can, however, be denominated a subset of a venerable, and amply codified, ethical mandate: the lawyer's duty to report a "violation of [any Disciplinary Rule] that raises a substantial question as to another lawyer's ... fitness ... to a tribunal or other authority empowered to investigate or act upon such [a] violation." 92 Prosecutors do not seem to be exempt from this obligation, ${ }^{93}$ and while for at least thirty years

Klein, The Emperor Gideon Has No Clothes, supra note 69, at 644-45 (arguing that inadequate counsel at trial prevents defendant from proving prejudice on appeal by failing to develop the record).

91. People v. Benevento, 91 N.Y.2d 708, 713 (1998) (interpreting N.Y. Const. art. I, § 6); People v. Baldi, 54 N.Y.2d 137, 146-47 (1981).

92. N.Y. Code, supra note 13, DR 1-103(A); see also Model Rules, supra note 83, R. 8.3, which uses almost identical language. Note that the Rule does not contemplate, but could be read to include, reporting misconduct to a judge presiding in a case, to an intra-organizational supervisor of an attorney in an institutional practice, or to a more general oversight body such as, in New York, the Indigent Defender Oversight Committee or the 18-B Panel Administrator.

93. Prosecutors are generally subject to the same professional standards and regulations as any other attorneys. See Fred C. Zacharias, Specificity in Professional Responsibility Codes: Theory, Practice, and the Paradigm of Prosectutorial Ethics, 69 Notre Dame L. Rev. 223, 248 n.82, 249 n.83, 269 (1993) (noting that prosecutors are subject to most professional requirements applicable to other lawyers); see also Bruce A. Green, Policing Federal Prosecutors: Do Too Many Regulators Produce Too Little Enforcement?, 8 St. Thomas L. Rev. 69, 73-74, 88-91 (1995) (noting that federal prosecutors are subject to state as well as federal disciplinary authority).

For about a decade, federal prosecutors attempted to claim exemption from some or all state-promulgated ethical codes, in response to increasingly broad interpretations of the prohibition on contacting adverse represented parties (codified in N.Y. Code, supra note 13, DR 7-104(A)(1) and Model Rule 4.2), and particularly in reaction to the sanctions imposed by the Second Circuit on an Assistant U.S. Attorney for violating that rule by working with a represented undercover informant. See United States v. Hammad, 858 F.2d 834, 838-40 (2d Cir. 1988). The ensuing controversy spawned a substantial literature. For an exhaustive step-by-step account, see the Winter 1992 Symposium issue of the Pittsburgh Law Review, especially John M. Burkoff, Prosecutorial Ethics: The Duty Not "To Strike Foul Blows", 53 U. Pitt. L. Rev. 271, 271-76 (1992); Roger C. Cramton \& Lisa K. Udell, State Ethics Rules and Federal Prosecutors: The Controversies Over the Anti-Contact and Subpoena Rules, 53 U. Pitt. L. Rev. 291, 318-24 (1992). While with the recent passage of the McDade Amendment, Congress has unequivocally expressed its position that federal prosecutors are and shall be subject to state and local federal ethies codes, one still cannot say whether any or all courts will accept that directive and exercise their inherent powers if called upon to impose discipline. See Citizens Protection Act of 1998, 28 U.S.C. § 530B (West Supp. 2000).

At least one state disciplinary body has issued an opinion specifically instructing prosecutors to report to disciplinary authorities an apparent conflict of interest on the 
commentators have decried its inefficacy ${ }^{94}$, since the unexpected and supposedly unprecedented 1989 decision of the Illinois Supreme Court in In re Himmel, ${ }^{95}$ it has assumed far greater salience. Limited as the enforcement of this Rule has been in the past, the possibility of future enforcement certainly garners attention.

While at first blush, this Disciplinary Rule seemed close to a clear command in this case, we quickly came up with a number of reasons it might not be applicable. First, if Mr. Defender's incompetence didn't qualify as ineffective assistance, could it still violate Canon 6? Second, was this "duty to report" really intended to apply in the context of

part of opposing counsel, i.e. the fact that a criminal defense attorney belongs to the same firm as the prosecutor in that jurisdiction. The opinion in no way grapples with the potential nuances of conflict of interest rules, and finds no special basis for the posited duty in the prosecutorial role, viewing prosecutors as just another species of lawyer mandated to report unprivileged knowledge of code violations. Bd. of Comm'rs on Grievances and Discipline, Ohio Adv. Op. 89-09, 1989 WL 535014 (Ohio Apr. 14, 1989).

94. In Wolfram's succinct phrase "Probably no other professional requirement is as widely ignored by lawyers subject to it." Wolfram, supra note 17 , at 683 . Wolfram quotes ABA Spec. Comm. On Evaluation of Disciplinary Enforcement, Problems and Recommendations in Disciplinary Enforcement (Clark Report) 167 (1970):

Although lawyers and judges have the necessary background to evaluate the conduct of attorneys and are far better equipped than laymen to recognize violation of professional standards, relatively few complaints are submitted to disciplinary agencies by members of the profession. This fact has been cited as a major problem by nearly every disciplinary agency in the United States surveyed by this Committee.

Id. at n.18; see also David R. Ramage-White, Note, The Lawyer's Duty to Report Professional Misconduct, 20 Ariz. L. Rev. 509, 512, 530 \& passim (1978) (concluding that majority of lawyers ignore DR 1-103(A) and fail to report unethical conduct; after having surveyed the Arizona bar to determine the willingness of lawyers to report misconduct and finding that "most Arizona lawyers would report, if at all, only the most serious infractions of the legal profession's ethical standards"); Ronald D. Rotunda, The Lawyer's Duty to Report Another Lawyer's Unethical Violations in the Wake of Himmel, 1988 U. Ill. L. Rev. 977, 982 (stating that it is "virtually unheard" of to find bar authorities enforcing this rule); John G. Bonomi, Do Lawyers Have Ethical Duty to Inform on Other Lawyers?, N.Y. L.J., Dec. 8, 1978, at 3 (former longtime bar counsel confessing that he is unaware of any instance in the history of New York of imposition of discipline for failure to report misconduct of another attorney; and observing that he was, at the time, the sole disciplinary counsel in New York ever to have tried to prosecute such a charge; even though the respondent in that case admitted to witnessing and not reporting bribery and obstruction of justice by another lawyer, he was acquitted).

95. 533 N.E.2d 790 (Ill. 1988) (upholding one-year suspension for failing to report another lawyer's conversion of client funds, in order to obtain restitution of funds for the cheated client). The decision and the stunned reaction to it are thoroughly described in Michael J. Burwick, Note, You Dirty Rat!! Model Rule 8.3 and Mandatory Reporting of Attorney Misconduct, 8 Geo. J. Legal Ethics 137 (1994). I call the decision "supposedly" unprecedented because, in fact, other notable decisions, albeit only a handful, had previously disciplined attorneys for failing to report misconduct. See, e.g., In re Dowd, 559 N.Y.S.2d 365, 366 (N.Y. App. Div. 1990). Himmel, however, is viewed as significant because it is the first instance of reported discipline based solely on the lawyer's failure to report another lawyer's misconduct. See Rotunda, supra note 94, at 982. 
actively opposed litigators? Third, did we "know" enough to make a judgment about Mr. Defender's competence? Fourth, should we take any steps that might be considered to constitute disparagement of Mr. Defender to his client?

\section{Does Mere Bad Lawyering by a Criminal Defense Attorney Violate the Disciplinary Rules?}

Is the unzealous, nonresponsive, confidence-revealing criminal defender violating an ethical duty, and, more to the point in this context, the Disciplinary Rule? The plain language of Canon 6, "A Lawyer Should Represent a Client Competently," is amplified by DR 6-101, which states, "A lawyer shall not ... [h] andle a legal matter without preparation adequate in the circumstances [nor] [n]eglect a legal matter entrusted to the lawyer," and by the gloss of EC 6-4: "The lawyer's obligation to the client requires adequate preparation for and appropriate attention to the legal work, as well as promptly responding to inquiries from the client." 96 The parallel provisions from the Model Rules of Professional Conduct require lawyers to offer their clients legal knowledge, skill, thoroughness, reasonably necessary preparation, diligence, and sufficient explanation of legal matters to enable the client to make informed decisions. ${ }^{97}$

True, the rare bench that overturns a conviction for ineffective assistance of counsel - which intuitively would seem a per se breach of Canon 6, etc. - virtually never reports the offending lawyer, ${ }^{93}$ and the

96. I am not even considering the alternative ground of violation under DR 6$101(\mathrm{~A})(1)$, which states, "A lawyer shall not: [h] andle a legal matter which the lawyer knows or should know that he or she is not competent to handle, without associating with a lawyer who is competent to handle it." See also Model Rules, supra note 83, R. 1.1. Were that the only basis of ethical responsibility for bad lawyers, it would be easy enough to escape on the ground that we cannot know whether the lawyer is competent, in some essential sense; we can only observe whether the lawyer appears to be, in the more existential language of DR 6-101(A)(2), "Failing to Act Competently" on this particular occasion. N.Y. Code, supra note 13, DR 6-101.

97. Model Rules, supra note 83, R. 1.1 (Competence), 1.3 (Diligence), and 1.4 (Communication).

98. Courts refuse to equate the two standards. Because of the additional requirement of demonstrating "prejudice" to sustain an ineffective assistance claim, it is possible for a lawyer to be disciplined for incompetence, but for the incompetently represented defendant's conviction to stand. See In re Wolfram, 847 P.2d. 94, 98 (Ariz. 1993); In re Agrillo, 604 N.Y.S.2d 171, 173 (N.Y. App. Div. 1993). If we were to take guidance from the jurisprudence of ineffective assistance as to what constitutes Canon 6 incompetence, we would know that it is not, for example, a complete lack of trial or criminal practice experience, see United States v. Cronic, 466 U.S. 648, 663-67 (1984) (sustaining conviction for felony mail fraud when appointed counsel, a young real estate lawyer, had only twenty-five days to prepare a case involving mountains of documents); use of narcotics during trial, see People v. Badia, 552 N.Y.S.2d 439, 440 (N.Y. App. Div. 1990) (upholding twenty-to-life sentence of defendant whose trial counsel, one month after trial, was indicted for and ultimately convicted of obstruction of justice and conspiracy to distribute drugs, and was proven to have been addicted to narcotics during trial); or, that perennial favorite, sleeping 
number of cases of discipline of any attorney, let alone a criminal defense attorney, for violations of DR 6-101 and its equivalents is vanishingly small..$^{99}$ We found no reported cases or ethics opinions or other commentary describing imposition of professional discipline on a criminal defender for inducing a client's confession to the authorities without (as seemed safe to surmise in our case) having properly advised the client of the potential risks. Nonetheless, Canon 6 and Model Rules 1.1, 1.3, 1.4 are unassailably applicable to the criminal lawyer. Mr. Defender's conduct would seem to nail just about every one of these grounds for discipline, even if it did not constitute ineffective assistance.

\section{Does the "Duty to Report" Encompass Adversary Misconduct?}

Given the potential of the adversary system to inspire vindictiveness and manipulation, it would not be surprising if courts, disciplinary tribunals, or professional rule-makers excepted lawyers in adversarial positions from a duty to report on one another. The purpose would be to eliminate the temptation to use a report of misconduct to distract an opponent or render the adverse party insecure about the quality of his advocate. Professor Green discussed this possibility, noting that "[a]ccusations of unethical conduct in the course of criminal proceedings, however, present the risk that false accusations

during trial, even when combined with illegal solicitation of an extra $\$ 5000$ fee despite prohibition on court-appointed counsel's seeking additional compensation for representation of indigent, see People v. Tippins, 570 N.Y.S.2d 581, $582-83$ (N.Y. App. Div. 1991) (holding that lawyer's sleeping during trial, although "reprehensible," was not sufficient to establish per se violation of constitutional right to counsel, even when combined with lawyer's subsequent criminal convictions for fraudulent and unethical fee solicitation), cert. denied sub nom. Tippins v. New York, 502 U.S. 1064 (1992), rev'd sub nom. Tippins v. Walker, 77 F.3d 682 (2d Cir. 1996). See also the recent reaffirmation that a lawyer who slept through substantial portions of prosecution witness testimony in a capital murder trial nonetheless rendered constitutionally adequate assistance under the Strickland standard, Burdine v. Johnson, 2000 WL 1610328 (5th Cir. 2000).

99. See Wolfram, supra note 17 , at 190,811 ("To date, the enforcement of competence standards has been generally limited to relatively exotic, blatant, or repeated cases of lawyer bungling. ... It is even rarer to find a disciplinary proceeding brought against a defense lawyer for incompetent representation."); Susan R. Martyn, Lawyer Competence and Lawyer Discipline: Beyond the Bar? 69 Geo. L.J. 705, 718 (1981). Of the relatively few cases in which lawyers have been prosecuted for neglect or incompetence, the emphasis is definitely on the civil side; criminal defendants, especially indigent defendants, are far less likely to file a complaint with the authorities. (That's also why indigent defense organizations have comparatively low malpractice insurance premiums.) For example, of the 100 or so cases cited in the annotations to Model Rules 1.1 and 1.3 in the ABA Center for Professional Responsibility's Annotated Model Rules of Professional Conduct 3-9, 26-30 (4th ed. 1999), only sixteen of these textbook examples of incompetence of counsel involved criminal proceedings. 
will undermine the relationship between defense counsel and the defendant." 100

As a policy matter, exempting adversaries from the general duty of mandatory reporting seems to make sense. The lost benefit, i.e. valid reports about adversaries, would seem minimal, since opposing counsel more rarely display their warts to one another than they do to colleagues or co-counsel. The trade-off is reducing the risk of frivolous or mischievous reports that are the product of retaliation, or just the jaundiced perspective of an adversary. Lawyers who did report another lawyer's misconduct in a non-adversarial setting might be more confident that because of the exception, their reports would receive greater credence. It might seem less likely that the first question on the report recipient's mind would be, "What grudge does Reporting Lawyer have against Reported Lawyer?"

Another reason to exempt adversaries from mandatory reporting would be to prevent neat orchestration of disqualification of the opposing party's chosen attorney. It is problematic enough, especially for a prosecutor, to make a motion to disqualify opposing counsel. ${ }^{101}$ Universally, it is suspected that the motive is not to protect the opposing party from the diluted loyalty of a lawyer who should be "conflicted" out of the case, and certainly not from that lawyer's inadequate effort or skill. It is assumed that disqualification motions are made for tactical advantage, and they often are viewed with disfavor for that reason. Ethics committees reviewing instances in

100. Green, Why Should Prosecutors "Seek Justice"?, supra note 8, at 624 n.76. The usual deterrent of potential defamation liability for a false or fallacious report may be absent, since there is at least some authority that would immunize all reports of professional misconduct. See San Diego County B. Ass'n Legal Ethics and Unlawful Practice Comm., Formal Op. 1992-2 (1992); The ABA/BNA Lawyer's Manual on Professional Conduct, Ethics Opinions 1991-1995, § 1001:1801 (1999): (illustrating that even in California, one of the three states without a mandatory duty to report in its ethical code, lawyer who does report another lawyer's misconduct is absolutely privileged); see also Weber v. Cueto, 568 N.E.2d 513, 517-20 (Ill. App. Ct. 1991) (granting absolute privilege for allegations that lawyer had misused public funds).

101. In recent years, a major ethics topic in prosecutorial circles has been the allegedly abusive use by prosecutors of motions to disqualify. See Bruce A. Green, "Through a Glass, Darkly": How the Courts See Motions to Disqualify Criminal Defense Lawyers, 89 Colum. L. Rev. 1201 (1989); see also Rodriguez v. State, 628 P.2d 950, 953 (Ariz. 1981) (holding that prosecutor lacked standing to move for disqualification of defense lawyer because of apparent conflict and stating in dicta, "If the State believed an ethical violation was occurring, it should have followed the guidelines of the Code of Professional Responsibility." Id. (quoting equivalent Code section of N.Y. Code, supra note 13, DR 1-103(A)). The court observed that "once... indigency is determined the county attorney has no standing to object as to who will or will not represent the defendant .... Not only does this strike at the very heart of the adversary system, but... for the prosecution to participate in the selection or rejection of its opposing counsel is unseemly if for no other reason than the distasteful impression which could be conveyed." Id. (quoting Knapp v. Hardy, 523 P.2d 1308, 1311 (Ariz. 1974)). 
which lawyers want to report or have reported adversaries during the pendency of litigation have viewed these complaints with suspicion, and denounced any hint that the reporter might be seeking to force settlement or merely throw the opposing lawyer and party off stride. ${ }^{102}$ Here, if we were to report Mr. Defender to disciplinary authorities for a violation of Canon 6, it was possible that not only he, but we, would end up off the case-him because of his "personal interest" in vindication in the disciplinary process, us, because of our potential role as witnesses in a disciplinary proceeding. ${ }^{103} \mathrm{Mr}$. Cliente might get a better defense lawyer, and he might be prosecuted by an ADA less engaged with domestic violence issues, and with less time to devote to the case. Would that be "justice" for Josetta?

\section{Did We "Know" That Mr. Defender was Incompetent?: The Scienter Element of the Duty to Report}

Another technical way out of the prosecutor's dilemma would be to follow the lead of some of the case law and commentary that demands a level of "knowledge" for purposes of the duty to report that no prosecutor would have to prove in order to establish scienter sufficient for a criminal conviction. ${ }^{104} \mathrm{My}$ favorite example of judicial envelope-pushing in this regard is the lengthy decision of the Mississippi Supreme Court in Attorney $U$ v. The Mississippi Bar. ${ }^{105} \mathrm{~A}$ case of first impression for that court-it noted that its research revealed only three cases nationwide on the subject of the duty to report-the court reviewed all the bar association ethics opinions and other authorities it could find, including quoting at length from the

102. See ABA Comm. on Ethics and Prof'l Responsibility, Formal Op. 94-383 (1994) (stating that lawyers must not file or threaten to file report with disciplinary tribunal as a tactical ploy in litigation); accord N.Y. State B. Ass'n Comm. on Prof'1 Ethics, Op. 635 (1992); see also Pa. State B. Comm. on Legal Ethics and Prof'l Responsibility, Informal Op. 97-40 (1997) (concluding that a lawyer who believes that opposing counsel, representing two parties, should be conflicted out, despite consent of both parties, has duty to report the conflict only if lawyer has firm basis to conclude that the dual representation will harm one or both of the opposing parties); The ABA/BNA Lawyer's Manual on Professional Conduct, § 101:207 (1999) (discussing the possibility that lawyer can bootstrap disciplinary complaint against adversary counsel into basis for disqualification). See also United States v. Jones, 900 F.2d 512 , 518-20 (2d Cir. 1990) (rejecting defendant's claim of ineffective assistance of counsel based on prosecutor's threat during trial to file a disciplinary complaint against defense counsel; on appeal, defendant alleged that defense counsel could not "make disinterested, objective tactical decisions or give... disinterested, objective advice" because of his concern about prosecutor's threat, which court dismissed as "hysterics"; in dictum, court indicated that claim of ineffective assistance could be sustained if threat of disciplinary action from prosecutor had "any basis in fact or law," because defense counsel might fear to engage in vigorous advocacy on behalf of defendant).

103. See N.Y. Code, supra note 13, DR 5-101, 5-102.

104. See id. DR 1-103; Model Rules, supra note 83, R. 8.3.

105. 678 So. $2 \mathrm{~d} 963$ (Miss. 1996). 
excellent treatment of this particular dimension of the duty to report by Geoffrey Hazard and William Hodes. As they cogently observe:

In terms of what can be proved, the "knows" standard thus begins to merge with the "should have known" standard, for often it will be impossible to believe that a lawyer lacked knowledge unless he deliberately tried to evade it. But one who knows enough to evade legally significant knowledge already knows too much.

…

...[T]here comes a point where only brute rationalization, moral irresponsibility, and pure sophistry can support the contention that the lawyer does not "know" what the situation is. ${ }^{106}$

If ever one would think that point had been reached, it would seem that Attorney $\mathrm{U}$ did in this case. ${ }^{107}$ However, while adopting an objective "reasonable lawyer" standard for deciding whether the respondent "had such knowledge as would enable him to testify as a witness" that another lawyer had violated a disciplinary rule, the Mississippi Supreme Court determined that the "unsworn description of a client" of the reported lawyer's misconduct did not constitute the requisite "clear and convincing evidence," such that "any reasonable lawyer would have formed a firm opinion that the conduct alleged by

106. Id. at 971 (quoting Geoffrey C. Hazard, Jr. \& W. William Hodes, The Law of Lawyering, $\S \S 402,403$ (1993)).

107. Attorney $U$ had been approached by the proprietor of a for-profit medical lab whose sole function was to perform pulmonary function tests on claimants who were seeking compensation or damages from asbestos manufacturers. Id. at $976 \mathrm{n} .2$. The lab-which seems to have been a rather unsavory set-up to begin with, since the proprietor had been a business agent for "a large union" (one could surmise, a union whose members comprised asbestos exposure victims)-entered into a thoroughly unethical fee-splitting arrangement whereby a plaintiffs' attorney referred his clients to the lab for "free" testing in exchange for promising the lab half of all legal fees eventually realized from the cases, plus some reimbursement of the medical costs, on a contingency basis. Id. at $976 \&$ n.2.

After a falling-out between the lawyer and the lab, the attorney hired another lawyer to represent him in negotiating with the lab, and explicitly took refuge in the unethical nature of the agreement. The lab retained Attorney U, who first tried to negotiate a flat, rather than contingent, fee for each patient/client tested that was almost ten times the going rate for equivalent testing elsewhere. Id. at 966 . When that was rejected by the plaintiffs' attorney, Attorney U warned him that Attorney U had advised his client, the lab, that it could file a grievance with the bar associationwhich, ultimately, it did. Id.

Subsequently, the plaintiffs' attorney filed a complaint against Attorney $U$, in part charging him with threatening to file a bar complaint in order to extort a settement for his client. Id. at 967. The Mississippi Bar Association found no probable cause to sustain that complaint. Instead, it filed its own formal complaint against Attorney $U$ on the sole ground of failure to report the fee-splitting conduct of the plaintiffs' attorney. Id. Attorney U's response was that he did not have "personal knowledge" that the plaintiff's attorney had violated any disciplinary rule, but knew only that the attorney had denied what Attorney U's client, the lab, had told him about the feesplitting. Id. at 968-69. 
[the] client had in fact occurred." 108 Therefore, the Court refused to sustain the complaint against Attorney U. ${ }^{109}$

In a vehement dissent, Justice McRae called the majority's inability to find scienter under these circumstances "incredible," and suggested that the majority ought, "[r]ather than insulting our intelligence... simply repeal a rule it so obviously dislikes," or "[b]etter yet, why not discard the Rules of Professional Conduct altogether?"110 The majority, he concluded, was paying "lip service" to the rules so that it could allow the respondent, "a partner in a distinguished Jackson law firm whose members include a former president of the Bar Association, to walk away without so much as a slap on the hand."111

Other less entertaining but more enlightening authority on this point includes the thorough report of the Committee on Professional Responsibility of the Association of the Bar of the City of New York (the "Committee"). ${ }^{112}$ The Committee emphasizes that "reporting alleged misconduct of another attorney is a serious charge" and warns that "[ $t]$ he damage done by reporting allegations as to which there is a substantial doubt of truth will, in almost all situations, outweigh the damage done by failing to report." ${ }^{113}$ Therefore, it adopts the standard set forth in EC 1-4: a lawyer must "believe clearly" that a violation of the Disciplinary Rules has occurred. ${ }^{114}$

In this case, our belief was crystal. We did not hear about Mr. Defender's conduct from a third party; we witnessed it. Moreover,

108. Id. at 972.

109. Id. at 973.

110. Id. at 975 (McRae, J., dissenting).

111. Id.

112. Ass'n of the Bar of the City of N.Y., Comm. on Prof'l Responsibility, Report: The Attorney's Duties to Report the Misconduct of Other Attorneys and to Report Fraud on a Tribunal, 47 The Record 905 (1992) [hereinafter Ass'n of the Bar of the City of N.Y., Attorney's Duties]; see also D.C. Bar Legal Ethics Comm., Op. 246 (1994). The D.C. Bar Legal Ethics Committee found that fairly blatant negligence, i.e., failing to meet a statutory limitations period for filing suit, does not necessarily raise "a substantial question as to [the] lawyer's ... fitness" and thereby trigger the duty to report. Id. (quoting Model Rule 8.3(a)). The Committee was reluctant to find that a single allegation of malpractice was tantamount to the lack of competence prohibited by Canon 6 or Model Rule 1.1. Id. The D.C. Bar Legal Ethics Committee was somewhat wishy-washy, however, leaving open the possibility that if it were clear to the inquiring lawyer that the malpracticing lawyer's conduct was willful or inexcusable, or if the facts of the particular case pointed to unfitness to practice law, the inquiring lawyer could "apply his own judgment" and decide whether a report was mandated. Id. See also Nassau County Bar Ass'n, Op. 98-12 (1998) (insisting that when inquiring lawyer learned opposing counsel had served as employment reference for client at the same time lawyer was making representations to tribunal that client was too disabled to work or pay child support, lawyer must determine for himself whether his "knowledge" of fraud on the court is sufficiently "actual" to require reporting). 10.

113. Ass'n of the Bar of the City of N.Y., Attorney's Duties, supra note 112, at 909 -

114. Id. at 910. 
our initial impression of Mr. Defender had only been reinforced by the reports garnered from other ADAs.

4. Is it Improper for Prosecutors to Comment to Defendants About the Qualifications and/or Quality of Representation of Opposing Counsel?

According to the American Bar Association Standards for Criminal Justice: Prosecution Function, Standard 3-1.3: Conflict of Interest (h): "A prosecutor should not ... comment upon the reputation or abilities of defense counsel to an accused person ... unless requested by such person." 115 The Commentary goes on to acknowledge that a "prosecutor may possess a natural and understandable interest both in who is representing an accused person ... and in how vigorously that individual is being represented.... [P]rosecutors are often uniquely well situated to assess the quality of the defense bar and defense representation in their jurisdictions." 116 However, "in the interests of the overall integrity of the criminal justice system, prosecutors should exercise great restraint when otherwise tempted to comment upon the reputation or abilities of particular defense counsel to an individual seeking defense representation... unless the issue has been directly raised in the first instance by th[at] individual ...."117

Plainly when they advise "great restraint," the authors of the Standard and the Commentary were not contemplating a prosecutor concerned about ineffective assistance of counsel. The envisioned conflict was between the interest of the accused in representation that would lead to exculpation, and the prosecutor's interest in the "justice" that generally consists of a conviction; in that context, the prosecutor should hesitate to opine to the defendant on the quality of a defense attorney. The Standard is redolent of the hesitation almost any lawyer feels about "bad-mouthing" an opponent to that opponent's client. It has little to do with fraternal protectiveness; lawyers generally do not exhibit the sort of united front of solidarity that, whether accurately or not, is attributed to police officers or medical doctors. There is just something unseemly and unsporting

115. ABA Standards for Criminal Justice: Prosecution Function and Defense Function Standard 3-1.3(h) (1993). See also National District Attorneys' Association Prosecution Standards, supra note 17, \& 25.6 ("When a prosecutor has knowledge of misconduct by defense counsel, the prosecutor has the responsibility to report that knowledge to the appropriate authority ...," and Commentary: “... If the prosecutor has a substantial basis for believing that misconduct [of defense counsel] exists, he should in all cases report that information to the appropriate authorities, at the same time being careful not to take action that would prejudice a defendant's right to a fair trial or precipitate a mistrial of the case. The timing of such report, therefore, may be an important element in a balanced approach to carrying out this responsibility.").

116. ABA Standards for Criminal Justice: Prosecution Function and Defense Function Standard 3-1.3 cmt.

117. Id. 
about detailing the flaws and foibles of your past or current adversary to a civilian.

And how, in practical terms, would we have managed to provide this information to Mr. Cliente? Even if we were trying to carry out our ethical duty, that would not necessarily excuse our contacting the defendant directly rather than through counsel ${ }^{118}$-at least, we could find no authority to suggest that it would. If we somehow rationalized that we could do so, what would we say? It would be an extremely delicate communication, difficult to craft and orchestrate. We would have to communicate with the defense counsel as well, if not simultaneously. To plan and manage all of this would be a major distraction from the important work that we knew was part of our role. We had all that we could do, in terms of energy and tasks, to maintain our relationship with Mr. Cliente's distraught wife, Josetta. We had both statutory ${ }^{119}$ and professional obligations to keep our complainant informed, to help her with safety planning (now that we knew about Mr. Cliente's contacts, we would provide her with a cellphone that dials only 911), to make referrals for culturally competent counseling and immigration status advice and legal assistance in Family Court, and housing and medical treatment for her and her two daughters - and this work was definitely our priority.

No, we were not prepared to reach out to Mr. Cliente and spend hours trying to explain enough about the adversary system and the duties of defense counsel to get across that his lawyer had messed up. What would that accomplish? What remedy, at this point, would he have? If he could obtain a new lawyer, a defender with enough sophistication to work with him on changing his attitude and his behavior, on compliance with the Order of Protection, on paying child support, maybe, just possibly, he could avoid a conviction. Highquality defense counsel can make a tremendous difference in domestic violence cases, especially by helping defendants understand the terms and the significance of court orders-which can redound to the victim's benefit. But this scenario seemed so unlikely. I just did not believe that a New York City Criminal Court judge-inured to the healthy percentage of lawyers in that court who never show up on

118. See supra note 35 . Recently a prosecutor was disciplined for contacting a defendant without the knowledge of the defense counsel. Although his primary offense was engaging in secret plea negotiations with the defendant without counsel's knowledge or consent, the prosecutor also filed a false affidavit with the court about the secret meeting, and then denied its occurrence to the disciplinary panel investigating the matter for two years, until finally he broke down and admitted it. In re Brey, 490 N.W.2d 15, 16 (Wis. 1992). In this context, his comments to the defendant about his lawyer's handling of the case pale, but the disciplinary body and the reviewing court did mention that they, too, were improper. Id. Now, guess what type of discipline the prosecutor received for all of this? Initially, he received a reprimand; on appeal, he received sixty days of suspension. Id. at 17.

119. N.Y. Crim. Proc. Law $\$ 530.11(2)$, (6) (McKinney 1995 \& Supp. 2000). 
time, who never speak to their clients, who never investigate a crime scene or look for witnesses or verify an alibi or work up a creative alternative sentence-would relieve Mr. Defender and appoint new counsel, whether at our request or Mr. Cliente's. I could hear the judge laughing now and saying, "Let me get this straight-you got an airtight, dead-on, all-bases-loaded confession, IN the presence of counsel, and now you're complaining?"

Moreover, putting Mr. Defender on the defensive about his having allowed Mr. Cliente to spill his guts to us could jeopardize our ability to use the incriminating statement if we did have to try the case. Hearing the judge's laughter, Mr. Defender might "forget" what his client had said and might find a way to induce Mr. Cliente to "forget" it also. Then, if the case went forward to trial and we needed to use it, it would turn into a swearing match. Not that I thought that two student assistant district attorneys and one law professor wouldn't look pretty credible, but in this business, you learn to take nothing for granted. There was no denying that strategically, we would be in a better position if the sleeping dog remained undisturbed. As far as we could tell, as long as no one suggested that Mr. Defender shouldn't have allowed Mr. Cliente to talk, it seemed a reasonable bet that neither the lawyer nor the defendant would try to deny that the statement had been made.

\section{THE DECISION: ARE WE ETHICALLY REQUIRED TO SPIT INTO THE WIND?}

By now, you have probably gathered that the decision we reached was not to intervene, not to report, and not to advise Mr. Cliente about his lawyer's deficits. It is still not easy to explain why. It was the product of an accumulation of many intangible factors.

First, the legalistic analysis seemed to indicate: (1) that our duty to "do justice" gives rise to a discretionary, rather than mandatory, duty to intervene, because Mr. Defender's bizarre behavior did not quite achieve the brain-dead level that defines a Sixth Amendment violation under the current case law; and (2) that we did have a much stronger and clearer obligation, pursuant to N.Y. Code DR 1-103(A), to report him to the disciplinary authorities-but not necessarily immediately, right in the thick of sorting out our more fundamental task of doing justice: determining the disposition and sentence to seek in the case against Mr. Cliente. ${ }^{120}$

120. Cf. Restatement (Third) of Law Governing Lawyers, $\$ 5 \mathrm{cmt}$. i (1998) (stating that common interpretation is that lawyer involved in litigation or negotiation is not required to report wrong-doing of another lawyer involved in that matter until its conclusion); ABA Comm. on Ethics and Profl Responsibility, Formal Op. 94-383 (1994) (implying lawyer may delay reporting if in interest of client); Ass'n of the B. of the City of N.Y., Comm. Profl. and Jud. Ethics, Informal Op. 81-100 (1982) (stating that lawyer should delay reporting pursuant to DR 7-102(B), if it would be 
An additional complication was the fact that we are not individual lawyers solely responsible for our ethical decisions. As members of a quite hierarchical office with a high public profile, we clearly could do nothing out of the ordinary routine without first consulting our superiors and taking it through channels. We could anticipate consuming many hours, not only of our time but of the officials who would have to be consulted, in discussion of the ramifications of any action, not just for this case but as a precedent within the District Attorney's office. The Pace Prosecution Clinic is a guest of the Manhattan D.A.'s office; like any guest, we do not want to abuse our welcome, or become more trouble than we are worth. Did we really want to bother Mr. Morgenthau with this tawdry tale of an encounter in a hallway in Criminal Court? Did we want to raise this issue, in the face of the observations by other assistants about this lawyer that seemingly had gone unreported? Would our taking action trigger a retaliatory "ethics war" in which defense lawyers would be looking to pounce on, for example, a hapless assistant handling a huge calendar of cases, who misread an instruction note from another ADA, and falsely announced that the People were ready to proceed when in fact that wasn't true?

Then, too, what would the disciplinary authorities do with a report if we made one? I knew, from personal experience as a pro bono trial counsel to the Disciplinary Committee of the Appellate Division, First Department, as well as from some study of the subject, that it could take years to resolve even a straightforward complaint about stealing funds. And would a disciplinary authority-could it?-impose a higher standard of performance on Mr. Defender than the exceedingly low threshold of ineffective assistance? Yes, courts did insist, in theory, that there was no necessary congruence between a reversal for ineffective assistance and the competence requirements of Canon 6 and Model Rule 1.1. ${ }^{121}$ But surely all Mr. Defender would have to do is assert his right to be wrong, to make mistakes, to try "risky and unorthodox" defense strategies, ${ }^{122}$ and that would be the

advantageous to client); Ass'n of the B. of the City of N.Y., Comm. on Prof'l Ethics, Formal Op. 1990-3 (1990) (finding some delay in reporting pursuant to DR 1-103(A) may be warranted to protect a client's interest). But see Conn. B. Ass'n Comm. on Prof'l Ethics, Op. 97-33 (1997) (obliging lawyer to report misconduct promptly and without waiting for outcome of pending lawsuit).

121. See supra note 98.

122. One reason courts profess to be so wary of meaningful enforcement of the right to competent counsel in the Sixth Amendment context is a concern that they might stifle risky and innovative lawyering strategies. See Tippins v. Walker, 77 F.3d 682, 686 (2d Cir. 1996) (stating that "in case after case," following Strickland, courts decline to deem counsel ineffective despite tactics that seem "risky, unorthodox or downright ill-advised"). Courts and the American Bar Association are also vigilant not to conflate "ordinary negligence" or errors of judgment or malpractice with the "neglect" that could sustain a disciplinary sanction. See Wolfram, supra note 17, at 188-89. 
end of the inquiry. Unwise, even foolish judgments by a lawyer are not the basis for ethical discipline.

In light of that, it might have made more sense (albeit not technically complied with the Code/Rules) to report our concerns to Mr. Defender's supervisors or those to whom Mr. Defender was accountable. ${ }^{123}$ Otherwise, they were unlikely to learn of our allegations; the 18-B Panel administrator, for example, has no way of knowing whether attorneys on the Panel have been disciplined by the Disciplinary Committee, unless an attorney seeking recertification to the Panel volunteers that information. Supervisors or administrators, unlike us, would be in a position to discuss what had occurred with Mr. Defender and probe to see if indeed there was some "expose the jugular" negotiating strategy, ${ }^{124}$ however misguided, in his mind.

There was no way, however, to recreate the surreal ambience of that encounter, and Mr. Defender would undoubtedly recast, if not outright deny, at least some of what had occurred. Our accusations would precipitate much Sturm und Drang in the small, intimate world of New York City's Criminal Court. Word would spread quickly, there would be charges and counter-charges, revival of the accusations that our student assistant district attorneys were too assiduous in their prosecution of minor cases, defense lawyers ostentatiously refusing to speak with us off the record, disapproving judges who would say that Mr. Defender was a fine, sensible, cooperative lawyer-hassle and bad feelings-maybe an article in the New York Law Journal before all was done. And, in the end, what would there be to show for it? In Criminal Court, people were used to snarling at one another, blaming one another, and exculpating themselves for its nonstop lunacies and tragedies. There is no ethos, in this setting, of taking responsibility for your actions, being grateful for trenchant criticism, or striving for ever better performance. There would be no constructive dialogue with anyone about what to do about Mr. Defender. Weary, overburdened, and cynical administrators at every level would end up muttering, "What's the difference? There's plenty more where he came from," and wishing that they didn't have to deal with these naive kids from law school and their ivory-tower professor, who just don't know the score. Mr. Defender would be back in no time-might even continue to represent Mr. Cliente. But we would have bought trouble for our case, and exacerbated the risk to Josetta's safety, which would disappear from center stage while the drama of the Bad Lawyer

123. In my deliberately obscure scenario, that might have been (1) a Legal Aid Society borough chief of the Criminal Defense Division, if Mr. Defender worked for Legal Aid; (2) the Indigent Defense Oversight Committee, if he worked for one of the contract defenders; or (3) the 18-B Panel Administrator, if he were a member of the rotating panel from the private bar assigned on a case-by-case basis.

124. Harry T. Edwards \& James J. White, The Lawyer as a Negotiator 118 (1977) (describing negotiation technique of "throwing oneself on the mercy of the opponent" by displaying the negotiator's weakness and reliance on the ethics of the opponent). 
played itself out over a series of adjournments, motions and countermotions, briefing schedules, and hearings in various venues. Our energies, supposed to be concentrated on the complexities of domestic violence prosecution and already stretched to the max as we tried to help as many complainants as we could, would instead be diverted to all of this activity. We might lose track of Josetta in the process - or his threats and wheedling, and the arduousness of her life without his economic and social support might wear her down-and what Mr. Defender had asserted might indeed come true, as it did in so many, many cases: our complainant would no longer be willing to testify or participate in the prosecution. Then things would really get ugly.

In the end, it did come down to the raw confrontation between our desire to help and protect an innocent victim - and you'll just have to trust me, Josetta was - and the $99.9 \%$-likely-to-be-futile effort to get the guilty Mr. Cliente a better lawyer. In the end, it wasn't even close.

\section{AN EXAMPLE OF CASUISTRY? CONTEXTUAL ETHICAL DECISION-MAKING INFORMED, BUT NOT CONTROLLED, BY THE RULES}

So, I must live with an outcome that I cannot explain as following a rule that I would universalize. Nor can I describe it as a justifiable departure from the rule that I would choose to universalize: i.e., that prosecutors ought to report unacceptably poor representation by defense counsel to those administrative personnel who potentially could act on the information to protect defendants from involuntary assignment of such lawyers, as well as doing whatever else prosecutors can to enhance the quality of that representation, including aggressive advocacy for adequate compensation and resources for the defense bar. Intellectually, this seems to me the right mandate. But, it's not what we did in this case.

It is hard not to see our decision as unprincipled expediency of the worst sort. The rules of ethics are there to direct our decision-making not when the choices are easy or clear, but when they are obscure and difficult. Even assuming I were a pure consequentialist, there is always the possibility that had I intervened to help Mr. Cliente get a new and better lawyer, he still would have been convicted and Josetta would have been protected. It's possible that Mr. Defender's next client will be another victim of family violence, a child or a woman who fought back against abuse and needs a skilled and diligent attorney, and because of my decision not to jeopardize, even slightly, Josetta (or do I mean to say, our case against Mr. Cliente?), Mr. Defender will replicate his parody of criminal defense at her expense. Will I have achieved real justice, then?

This Symposium, of course, reminds us that there is another theory of ethical decision-making, one that promises to absolve me of both 
my deontological sin and my consequentialist failure. I don't think I can improve on the description of the merits of this approach found in Professor Paul R. Tremblay's essays, The New Casuistry $y^{125}$ and the earlier The Role of Casuistry in Legal Ethics: $A$ Tentative Inquiry. ${ }^{126}$ If I have grasped it right, casuistry would allow me to couple my "answer" in this case with the assertion that in another case, with another complainant, perhaps one with more social support, emotional resources, and safety options than Josetta, I might make a different decision - and that both decisions, in a real sense, could be deemed "right."

Going all the way back to Professor Monroe Freedman's pathbreaking article on prosecutorial ethics, ${ }^{127}$ he was perhaps the first to argue, at least in regard to the practice of law, for a "system of professional responsibility" that "attempts to deal with ethical problems in context, giving full consideration both to motive and consequences" rather than one that "rests upon rigidly legalistic adherence to norms, regardless of the context."123 The last line of that article summarizes the starting point of the casuistrist:

[W] should no longer delude ourselves that the complexities of what constitutes responsible professional conduct in the context of an adversary system can be resolved by syllogistic deductions from vague canons or dogmatic prescripts. ${ }^{129}$

It is, indeed, altogether comforting to think that the decision to privilege Josetta's safety over our role-prescribed duty to intervene with or report Mr. Defender reflects the kind of "ethical inquiry" lauded by Professor Phyllis Goldfarb in A Theory-Practice Spiral: The Ethics of Feminism and Clinical Education. ${ }^{130}$ Professor Goldfarb writes:

From feminists' and clinicians' relentless demand for elaborate concrete detail and for special attention to the data provided by those whom society frequently disempowers comes a reconceived notion of what qualifies as ethical inquiry.... The focus of ethical theory is no longer the justification of actions affecting the "generalized others" of traditional philosophy, but the justification of actions affecting the "concrete others" with whom we are enmeshed.... In the hands of feminists and clinicians, ethics becomes a sustained practice of empirical attention and reflection on the actions of people in actual situations. ${ }^{131}$

125. Supra note 19.

126. 1 Clinical L. Rev. 493 (1994).

127. Freedman, The Professional Responsibility of the Prosecuting Attorney, supra note 43.

128. Id. at $1046-47$.

129. Id. at 1047.

130. 75 Minn. L. Rev. 1599 (1991).

131. Id. at 1697-98 (internal citations omitted). 
Yet, I confess to lingering doubt that "attention and reflection," however sustained, is necessarily always a satisfactory substitute for the categorical imperatives of code-like rules. The limitations of the case-based model of ethical decision-making are thrown into higher relief for me by my experience as a teacher. Too often my students seem too eager to "trust their instincts" and "feel" their way toward a solution to their dilemmas. They will happily engage in a "sustained" conversation about the issue, but are less willing to go to the library and research the thinking of other lawyers embodied in rules, ethics committee opinions, and judicial decisions.

Different approaches to ethical decision-making may be appropriate for the more and the less experienced. Maybe it takes years of assiduous compliance (or at least attempts to comply) with the absolute Kantian imperatives of the letter of the law, or more years of utilitarian calculus, to develop the capacity to see the contextual details that enable us to use casuistry instead. Paul Tremblay himself suggests as much:

Casuistry not only demands context, but it also insists upon a form of expertise. All practitioners are not equally "wise." Those who are better at casuistry, and therefore at moral reasoning itself, are those who have developed the wisdom... necessary to develop considered moral judgments. ${ }^{132}$

How, though, do we know that we have arrived at this point - that we have acquired this "wisdom"-if not by comparing our outcomes, not just our process, with something external to and independent of our own judgments? If not rules and principles, then what? The "paradigm cases?" Can those be not cases that you've read about, but cases that you've lived?

On reflection, I suspect that my decision about Mr. Defender was grounded in far deeper knowledge and experience than my students could muster-a kind of "been there, tried that" experiential erudition that enabled me to predict, for example, that had I reported Mr. Defender, most likely he would not have lost his job/18-B Panel certification; that he would have continued representing other defendants and even, quite possibly, continued representing $\mathrm{Mr}$. Cliente; that, had any kind of authoritative inquiry ${ }^{133}$ alerted him to the notion that the quality of his defense was being examined, and

132. Tremblay, The New Casuistry, supra note 19, at 522.

133. The typical practice of the First Department Disciplinary Committee, for example, had that been my chosen route, would have required me to file a short written complaint, which would have been sent to its subject, the "respondent," for an answer. The complaint is not anonymous; in most cases, as in this one, the identity of the grievant would be instantaneously identifiable.

Had I instead filed a complaint with the Legal Aid Society or with the 18-B Panel or with the Indigent Defense Organization Oversight Committee (responsible for assessment of all the contract providers in the First Department), a slightly less formal process would have amounted to the same basic procedure. 
that I was the instigator of the inquiry, he would have waxed far more zealous and vigilant on behalf of Mr. Cliente, with deleterious results for the innocent victim. Perhaps on balance, "all things considered," we did, after all, do something like the right thing. Of course, the response - if any-to this article may change my mind about some of these underlying assumptions. Or, possibly, its writing and publication will prompt some discussion and reflection within the offices of district attorneys about the need to develop clear rules, or at least articulated policies, that will not leave individual assistants trying to chart a casuistric course by the hazy stars of DR 6-101 and DR 1103(A), and "the duty to do justice."134

\section{CONCLUSION: DOES CASUISTRY BELONG IN THE REPERTOIRE OF THE PROSECUTOR?}

As may be obvious, I have hardly reached a state of clarity or equilibrium about either what I did in the case of Mr. Cliente and Mr. Defender, or what I would do in the next such case. It is worrisome and unsettling, this sense of bridled, but essentially self-directed, discretion. I suppose it is part of my ongoing initiation into the moral complexity of the prosecutorial role, a complexity that continues to startle my Inner Defender, who keeps wanting to say that while I love the righteous feeling of being licensed to do justice - and cherish it as the unique privilege that, for lawyers, it is - still, the prosecutorial role lacks the tragic grandeur, and its ethical challenges the gravitas, of those of the criminal defense lawyer. Right???

As a defense lawyer, what I felt was not merely ambivalence about my work; it was far more multi-layered than that. My every reaction provoked not just an equal and opposite reaction, but a cascade of multiple chain reactions in all directions. Delight mingled with disgust when I bamboozled an ignorant judge or charmed a sexist one into letting out of jail a client who was undoubtedly guilty - but who just as surely did not belong in jail. Winning an acquittal brought rapture and ecstasy, only to be deflated almost immediately by the grim prognosis for my client as he emerged from jail after twenty-two months without a home, a friend, or a future that could be imagined. Near-homicidal fury possessed me when a miserable, lonely, and mentally-impaired man or woman accused, and generally guilty, of some petty crime was treated with casual, callous, unnecessary cruelty by police officers and court officers and corrections officers and probation officers and, not infrequently, judges and prosecutors - and

134. Cf. Zacharias, Justice in Plea Bargaining, supra note 62, at $1182-89$ (stating that prosecutors' offices should specify models of plea bargaining and develop uniform "ex ante" plea-bargaining policies); see also Roberta K. Flowers, A Code of Their Own: Updating the Ethics Codes to Include the Non-Adversarial Roles of Federal Prosecutors, 37 B.C. L. Rev. 923, 963-64 (1996) (stating that prosecutors need more specific direction from ethical codes). 
other defenders. I learned that legally, there was really nothing I could do to stop the abuse, nor to puncture the lazy, uncaring, unprofessional, shallow, and benighted attitudes that fostered it. That fury would quickly reverse field into a less intense but still debilitating anger when clients "got themselves" re-arrested after I had knocked myself out getting them released, or when they wanted to plead guilty but balked at accepting a short jail sentence because a diabolically clever judge was dangling five years of probation in front of them, ${ }^{135}$ or when they did any of a number of other self-destructive things. I had no idea that prosecutors ever suffered torments remotely parallel to these.

In time, my neophyte panic as a "baby defender"136 that I didn't know how to do anything, and then that I couldn't do everything I had to do, was superseded by episodic, but recurrent, moments of pride and wonderment that I was managing to function and even derive considerable satisfaction from the devotion of every molecule of my being to this enterprise. Those moments, though, were interspersed with more and more puzzlement about the meaning and impact of the work. ${ }^{137}$ Pace my dear and much-admired colleague Professor Abbe Smith, comparisons to Atticus Finch in To Kill a Mockingbird did not, for me, ring true. ${ }^{138}$ It was about this point that I encountered the then-burgeoning field of bioethics, and found in the messy multiparty, multi-polar constellations of medical decision-making about

135. For some of my clients, it was statistically more likely that they would win the Nobel Peace Prize than complete probation in the next five years without violating its terms and subjecting themselves to a far stiffer sentence of incarceration than the one offered at the time of the plea. For those who could take care of themselves reasonably well in jail-a category one learned to identify as a defense lawyer-six months on the Rock (Riker's Island, in the East River, location of the New York City Correctional Institute for Men, where sentenced prisoners doing less than a year were housed in conditions that were not intolerable, though extremely unpleasant, and, most important, which was not too far from family and friends) would be a much better deal than the seven years upstate that the judge would give them with relish, when, inevitably, they got drunk, stoned, or arrested while on probation. Judges knew this as well as I did, and would play on the defendant's desperate hope that somehow, this time, he would manage to pull off the five years on probation.

136. For some reason, first-year lawyers on both sides of the aisle at 100 Centre Street are tagged as "baby defenders" or "baby prosecutors" or "rookies."

137. For a truly eloquent exposition of the "meaning" of defense work by a lawyer who suffers a horrendous family loss from a random crime, but whose moral commitment to his work is undiminished, see Charles J. Ogletree, Jr., Beyond Justifications: Seeking Motivations to Sustain Public Defenders, 106 Harv. L. Rev. 1239 (1993).

138. Professor Smith of Georgetown is one of the most prolific and incisive scholars to scrutinize and synthesize theories of the criminal defender's professional role. I continue to read her work with thrills of recognition because she gets it all so right. In more than one of her often partially autobiographical pieces, she alludes to the impact of the image of Atticus Finch in Harper Lee's To Kill A Mockingbird (1960) on her pride and satisfaction in that role. See Abbe Smith, Rosie O'Neill Goes to Law School: The Clinical Education of the Sensitive New Age Public Defender, 28 Harv. C.R.-C.L. L. Rev. 1, 51-52 (1993). 
scarce resources, personal responsibility, autonomy versus paternalism, and the like, problems and issues that were reminiscent of my own questions and worries, and that wooed me away from the starkly bipolar world of criminal defense. At that time, in the early 1970 s, there was precious little in the legal ethics literature that resonated with the volatile mixture of bliss and agony that seemed to be my lot at 100 Centre Street. ${ }^{139}$

I ended up spending many years immersed in the field of bioethics, gradually expanding into other fields of professional ethics, eventually

139. It is remarkable, in retrospect, to realize how few of the works that now serve me as compasses, if not maps, in times of professional confusion were extant at that time. Before the Model Code was promulgated in 1969, there was no real set of enforceable, prescriptive rules for the legal profession; its predecessor, the American Bar Association Canons of Ethics of 1908 amounted to more of a "creed" than a "code." James E. Moliterno, Lawyer Creeds and Moral Seismography, 32 Wake Forest L. Rev. 781, 794 (1997). Legal ethics, of course, was not a required course in American law schools; there was no Multistate Professional Responsibility Examination. Monroe Freedman's Lawyers' Ethics in An Adversary System, supra note 43, did not come out until 1975, the same year as Richard Wasserstrom's Lawyers as Professionals: Some Moral Issues, 5 Hum. Rts. 1 (1975) (although what would become key chapters in Freedman's book, The Professional Responsibility of the Prosecuting Attorney, 55 Geo. L.J. 1030 (1967) and Professional Responsibility of the Criminal Defense Lawyer: The Three Hardest Questions, 64 Mich. L. Rev. 1469 (1966), had appeared almost a decade earlier). The first "casebook" for clinical courses, Gary Bellow's and Bea Moulton's The Lawyering Process: Materials for Clinical Instruction in Advocacy, published in 1978, was permeated with ethical decision-making of depth and sophistication; there shortly followed the inimitable Becoming A Lawyer: A Humanistic Perspective on Legal Education and Professionalism (Elizabeth Dvorkin, Jack Himmelstein and Howard Lesnick eds.), published in 1981 although first issued in a monograph in 1980. The Politics of Law: A Progressive Critique, David Kairys' superb collection of critical essays on the functions of law and lawyers, was published in 1982. Charles Wolfram's Modern Legal Ethics, supra note 17, came out in 1986 to replace Henry Drinker's longoutdated Legal Ethics (1953).

It is no surprise, then, that in the early and mid-1970s, the concepts and vocabulary for going beyond a superficial analysis of the why's and wherefore's of lawyering were not readily available. The only text I can recall at that time that really addressed the angst of the criminal defense lawyer was David Mellinkoffs The Conscience of A Lawyer (1973), a wonderful exposition of nineteenth-century British murder cases, with examples of the opprobrium heaped on the lawyers who defended the accused and their spirited responses. Mellinkoff raised powerful arguments for the overriding values of loyalty to clients and confidentiality of client communications, and addressed the pressures defense lawyers endure from a hostile citizenry, but did not really describe or deal with any internal conflict or self-doubt on the part of these lawyers.

In 1969, the newly-minted American Bar Association Code of Professional Responsibility supplanted and certainly improved upon the 1908 Canons. But as a response to the pervasive dismay, malaise, and anxiety that characterized my defense lawyer persona, the new Code's rules and even its Ethical Considerations seemed very limited. They were still too much the "vaporous platitudes... which have somewhat less usefulness as guides to lawyers in the predicaments of the real world than do valentine cards as guides to heart surgeons in the operating room" in the classic phrase of Anthony Amsterdam, one of the most renowned criminal defense lawyers and teachers of lawyering ever. Wolfram, Modern Legal Ethics, supra note 17, at 55 n.29 (quoting Time, May 13, 1966, at 81). 
refocusing primarily on legal ethics, precisely because of the relentless need I had experienced as a criminal defense lawyer to better understand the moral implications of what I was doing. Despite the exalted place of certain principles in much bioethical analysis, ${ }^{140}$ bioethics is also the locus of a prolonged rehabilitation of the casuistric method. ${ }^{141}$ So the concept is hardly foreign to me, although I have to admit, until the invitation to participate in this Symposium, it had been a very long time since I had given it much thought.

When this summer I found myself returning again and again in my thoughts and ultimately on my computer to the story of Mr. Defender and $\mathrm{Mr}$. Cliente, with a continuing sense of mingled shame and contrition over how it was handled, I was happy to renew my acquaintance with the principle of casuistry (if that isn't too much of a contradiction in terms). In fact I quite seized upon the idea that my inaction in this case was not merely lawless, self-indulgent, or selfprotective, but rather the product of a complex and inarticulable process of "deliberative judgment," to borrow one revered scholar's term, ${ }^{142}$ or of a "case-based, particularized, context-driven method of normative decision-making." 143 I would like to think, of course, that perhaps we did arrive at "the best solution, all things considered." 144 The notion that hard decisions can legitimately be grounded in "practical ethics" or "prudence" is naturally attractive to a clinician who has taught and studied and practiced and reflected on clinical decision-making, decision-making under conditions of uncertainty, and the exercise of clinical judgment in medicine, in law, and in other professions for nearly twenty years.

And yet ...

I am not wholly convinced. In the same Symposium issue in which Paul Tremblay does such an excellent job of presenting the virtues of casuistry as a mode of ethical problem-solving, the author of the

140. See, e.g., Tom L. Beauchamp \& James F. Childress, Principles of Biomedical Ethics (4th ed. 1994).

141. See, e.g., Symposium, Emerging Paradigms in Bioethics, 69 Ind. L.J. 945 (1994); John D. Arras, Principles and Particularity: The Role of Cases in Bioethics, 69 Ind. L.J. 983 (1994); Franklin G. Miller et al., Clinical Pragmatism: John Dewey and Clinical Ethics, 13 J. Contemp. Health L. \& Pol'y 27 (1996); Susan M. Wolf, Shifting Paradigms in Bioethics and Health Law: The Rise of a New Pragmatism, 20 Am. J.L. \& Med. 395 (1994); see also Judith C. Ahronheim, et al., Ethics in Clinical Practice (1994); A.R. Jonsen et al., Clinical Ethics (3d ed. 1992); Terry M. Perlin, Clinical Medical Ethics: Cases in Practice (1992); Robert M. Veatch, Case Studies in Medical Ethics (1977).

142. See Anthony T. Kronman, The Lost Lawyer: Failing Ideals of the Legal Profession 40-44; 264-70; 326-27, 362, 375-76 (1993) (arguing that lawyers should be trained in law school to exercise "practical wisdom"-more an attribute of character than a skill - and lawyers' distinctive expertise: the craft of handling particular cases while recognizing their peculiarities, idiosyncrasies, and moral complexities).

143. Tremblay, The New Casuistry, supra note 19, at 492.

144. Id. at 520 . 
Foreword, Heidi Li Feldman, points out some of the risks. ${ }^{145}$ Vivid, concrete examples of moral dilemmas that allow the reader or hearer to "vicariously inhabit" the ethical world-view of others surely can be instructive occasions for thinking about professional ethics, but they should not be too readily reduced to "sloppy conclusions" in an attempt to "immediately deriv[e] principles or judgments." 146 Can I really be confident that the next time I confront an abysmally bad defense lawyer (and there will be a next time-probably within the next few months), I will make the "best" decision, "all things considered"? ${ }^{147}$ If I have no moral compass in the form of at least a presumptive rule (e.g., "unless there's a really good reason not to, I will report that lawyer"), but instead have to make my way via "moral triangulation," 148 will I generate the moral momentum to overcome the hard-to-explain but powerful internal resistance to doing something about that lawyer that I now know I will feel?

Especially in the prosecutorial context, the very epicenter of untrammeled lawyering discretion, a place where norms of fairness and consistency must be so scrupulously observed, casuistry may not work. Most lawyers do not have as strong a role-obligation to make sure that each client or each case is treated exactly the same way. For prosecutors, treating categorically similar cases differently-even when an adequately "thick description" of the cases ${ }^{149}$ might highlight valid distinctions among them-is problematic. ${ }^{150}$ We do not have the luxury of devoting as many hours as it has taken to write this article to explaining the nuances of each case to a community often already suspicious of our bona fides. A compelling example of the potential of such an approach to make mischief is found in Angela J. Davis' Prosecution and Race: The Power and Privilege of Discretion. ${ }^{151}$

Professor Davis begins her essay by describing a case she encountered in 1987, during her years of practice with the Public Defenders Service for the District of Columbia ("PDS"). ${ }^{152}$ It was a case in which a prosecutor utilized his discretion to do what many in the criminal defense community would like to see more often: to

145. Heidi Li Feldman, Foreword, Beyond the Model Rules: The Place of Examples in Legal Ethics, 12 Geo. J. Legal Ethics 409, 431-32 (1999).

146. Id. at $430-31$

147. Tremblay, The New Casuistry, supra note 19, at 520.

148. Id. at 518,534 .

149. See id. at 521; Paul R. Tremblay, Coherence and Incoherence in Values-Talk, 5 Clinical L. Rev. 325, 328 n.2 (1998).

150. See James Vorenburg, Decent Restraint of Prosecutorial Power, 94 Harv. L. Rev. 1521, 1554-57 (1981) (calling for a vast reduction in prosecutorial discretion, in part because "prosecutors can and do accord different treatment ... on grounds that are not written down anywhere and may not have been either rational, consistent, or discoverable in advance;" "a discretionary system ... always carries the potential for invidious discrimination ...." (emphasis in original) (internal quotations omitted)).

151. 67 Fordham L. Rev. 13 (1998).

152. Id. at 13-17. 
affirmatively seek out exculpatory evidence, present it to a grand jury, and allow the grand jury to return no bill-something that had never happened in a homicide case before in Professor Davis' experience and that of her PDS colleagues. But they did not celebrate this as a breakthrough. Why? Because the defendant was a young white college student who had hacked to death with a machete his roommate, a middle-aged Vietnamese restaurant worker. The race, class and other statuses of the defendant and the victim were the only factors that seemed to explain the prosecutor's unprecedented exercise of discretion. Whatever the "practical wisdom" of that prosecutor, it was a poor choice to make this case the occasion to depart from the routine treatment of murder. So here, perhaps, is yet another way in which prosecutors are different. Among all the varied types of lawyers for whom it might be advisable and advantageous to embrace casuistry, not only for them and their clients but for the larger community as well, perhaps the one role that does not and should not lend itself to an even more amorphous definition of ethical responsibilities is the prosecutorial. Just as with the traditional codes' familiar admonition that the "public prosecutor cannot take as a guide for the conduct of his office the standards of an attorney appearing on behalf of an individual client," in this post-modern age of redefined professional ethics, ${ }^{153}$ prosecutors may be confined to a more circumscribed repertoire of ethical decision-making than our privatesector counterparts. That is, ironically, because prosecutors enjoy such broad discretion as "the most powerful lawyers," 154 it is all the more crucial that we appear to be, and are, reined in by scrupulous adherence to principles and rules-even the peculiar challenge posed by rules like DR 1-103(A) and Model Rule 8.3.

As Professor Davis wrote:

Prosecutors have been given more power and discretion than any other criminal justice official, so they have a greater ability to effect change where it is needed.... They can, and should, set a higher standard of performance for themselves than the requirements set by the Supreme Court. ${ }^{155}$

When it comes to our duty vis-a-vis an incompetent defender, Professor Davis would surely agree that prosecutors ought to meet a higher standard than that set by the Strickland Court. ${ }^{156}$ Considerations that could be deemed "contextual"-the degree of

153. See, e.g., Carrie Menkel-Meadow, The Trouble With the Adversary System in a Postmodern, Multicultural World, 38 Wm. \& Mary L. Rev. 5, 37-44 (1996); Monroe H. Freedman, The Trouble With Postmodern Zeal, 38 Wm. \& Mary L. Rev. 63 (1996); see also Drucilla Cornell, Toward A Modern/Postmodern Reconstruction of Ethics, $133 \mathrm{U}$. Pa. L. Rev. 291 (1985).

154. Green, Why Should Prosecutors "Seek Justice"?, supra note 8, at 625-30.

155. Davis, supra note 151, at 67.

156. See supra note 69. 
certitude about a particular defendant's guilt, the perceived need to protect a particular civilian victim with limited resources, a conviction that it would be futile to complain to a particular presiding judge or to the disciplinary authorities in that jurisdiction - may, in fact, have no legitimate place in the prosecutor's ethical analysis.

I know that I concur with those who would reverse the current thrust of Sixth Amendment jurisprudence: that each inquiry is factspecific, that there is and can be no "checklist" of appropriate defense actions that, when neglected wholesale, establishes a prima facie case of ineffective assistance, etc. ${ }^{157}$ The quality of a defendant's counsel should not be determined as normlessly as it is now. ${ }^{158}$ It may well be that casuistry, a decision-making technique that lets prosecutors exercise their enormous discretion with even greater "case-by-case" latitude, is a tool that too easily can serve the powerful. ${ }^{159}$ It is the less powerful lawyers - those who represent the poor and disadvantagedwho need and should have the right, when making decisions about professional role and responsibilities, to take into account the concrete realities of their particular clients' lives in the actual context of those lives. Judges and prosecutors - those in the legal system who are privileged with power-need more structured and extraneous constraints.

\section{CODA}

Just before sending this article off to Fordham Law Review, I received a draft manuscript from Abbe Smith, the quintessential defense lawyer, with the engaging title, "Can You Be a Good Person

157. See Calhoun, supra note 69; Klein, The Relationship of the Court and Defense Counsel, supra note 11, at 578-84 (arguing that courts should conduct pretrial conferences and require pretrial checklists in criminal cases, to ensure adequate preparation, which can be "objectively assessed"); see also William W. Schwarzer, Dealing With Incompetent Counsel-The Trial Judge's Role, 93 Harv. L. Rev. 633, 649-665 (1980) (outlining "guidelines for intervention and assessment of attorney performance" at every phase of the criminal pretrial and trial process). Reading the case law on ineffective assistance, with all its talk about the "judgment" that is presumed to have been exercised by the defense lawyer, is all too reminiscent of the "new casuistry."

158. See, e.g., People v. Ellis, 81 N.Y.2d 854, 856 (N.Y. 1993) (finding there can be no "litmus test" for ineffective assistance); People v. Garcia, 75 N.Y.2d 973, 974 (N.Y. 1990) (holding that to establish ineffective assistance, defendant must show that counsel could have had no conceivable strategic or legitimate purpose).

159. I am reminded here of the policy disagreements about another decisionmaking tool praised for its freedom from inflexible norms, but suspect when used in the context of an imbalance of power: mediation in domestic violence cases. See Linda $\mathrm{K}$. Girdner, Mediation, in ABA Comm'n on Domestic Violence, The Impact of Domestic Violence On Your Legal Practice, A Lawyer's Handbook, 4-17 to 4-20 (Deborah M. Goelman et al. eds. 1996); Lisa G. Lerman, Mediation of Wife Abuse Cases: The Adverse Impact of Informal Dispuse Resolution on Women, 7 Harv. Women's L.J. 57 (1984). 
and a Good Prosecutor?"160 A typically wise, wonderful, and wicked product of Professor Smith, it capsulizes all that I have written above into a few sentences:

[W] hy have I never encountered-or even heard of a single prosecutor who has come forward to halt a trial in the face of plainly incompetent defense counsel? The right to competent counsel is central to every other right of the criminally accused, and the denial of that right threatens the foundation of adversarial justice. Surely, prosecutors have an ethical obligation to do something - and not just take advantage - when they encounter a plainly ineffective defense lawyer.

There are instances of incompetent, drunk, hung-over, and sleeping lawyers representing the indigent accused in every courthouse in the country, but there is never any mention of the other institutional actors who are present doing anything about it. The prosecutor[s] clearly know [] what is going on ... why don't they at least approach the bench and make a record of the incompetence they observe? ${ }^{161}$

Next time, Abbe, I hope to do better. ${ }^{162}$

160. Manuscript on file with the author.

161. Id. at $71-73$ (footnote omitted).

162. The somewhat disapproving tone of comments received on earlier drafts of this piece has chastened me into doing what originally I had deliberately chosen not to do: tell the ending of Mr. Cliente's story. After all this fulmination, as so often happens in Criminal Court, fate intervened. Mr. Cliente continued to violate the temporary Order of Protection, eventually resorting to more violence against Josetta; he was indicted for felonious Criminal Contempt, at which point it was discovered that Mr. Defender was not certified to represent defendants on felonies. The new attorney on the felony matter was directed to undertake Mr. Cliente's representation on our pending misdemeanors, and ultimately they were subsumed into the disposition on the felony. All of this, most likely, would have occurred long before the resolution of a complaint about Mr. Defender or the appointment of new counsel for Mr. Cliente. 